\title{
Bacterial Contamination Study of Loose-Fitting Power Air Purifying Respirators (PAPR) Compared to N-95 FFR and Surgical Mask, in a Simulated Sterile Environment
}

Tyler J. Church

tjchurch@mix.wvu.edu

Follow this and additional works at: https://researchrepository.wvu.edu/etd

Part of the Occupational Health and Industrial Hygiene Commons

\section{Recommended Citation}

Church, Tyler J., "Bacterial Contamination Study of Loose-Fitting Power Air Purifying Respirators (PAPR) Compared to N-95 FFR and Surgical Mask, in a Simulated Sterile Environment" (2019). Graduate Theses, Dissertations, and Problem Reports. 3901.

https://researchrepository.wvu.edu/etd/3901

This Thesis is protected by copyright and/or related rights. It has been brought to you by the The Research Repository @ WVU with permission from the rights-holder(s). You are free to use this Thesis in any way that is permitted by the copyright and related rights legislation that applies to your use. For other uses you must obtain permission from the rights-holder(s) directly, unless additional rights are indicated by a Creative Commons license in the record and/ or on the work itself. This Thesis has been accepted for inclusion in WVU Graduate Theses, Dissertations, and Problem Reports collection by an authorized administrator of The Research Repository @ WVU. For more information, please contact researchrepository@mail.wvu.edu. 


\section{Bacterial Contamination Study of Loose-Fitting Power Air Purifying Respirators (PAPR) Compared to N-95 FFR and Surgical Mask, in a Simulated Sterile Environment}

\section{Tyler Church}

Thesis submitted to the Statler College of Engineering and Mineral Resources at West Virginia University

in partial fulfillment of the requirements for the degree of

Master of Science

In

Industrial Hygiene

Xinjian He, Ph.D., Chair

Steven Guffey, Ph.D.

Ziqing Zhuang, Ph.D.

Department of Industrial and Management Systems Engineering

\section{Morgantown, West Virginia}

2019

Keywords: PAPR, Bacterial Contamination, N-95, Surgical Mask, CFU Copyright 2018: Tyler Church 


\section{Abstract \\ Bacterial Contamination Study of Loose-Fitting Power Air Purifying Respirators (PAPR) Compared to N-95 FFR and Surgical Mask, in a Simulated Sterile Environment}

\section{Tyler Church}

Powered air purifying respirators (PAPRs) are commonly used in a health care setting, providing a higher level of protection than traditional surgical masks or N-95's. However, little can be found in literature about their use in a sterile environment, such as an operating room. Thus, this study aims to compare bacterial contamination of three different models of PAPRs $\left(3 \mathrm{M}^{\mathrm{TM}}\right.$ Versaflo $^{\mathrm{TM}}$ TR-600-ECK, 3M ${ }^{\mathrm{TM}}$ Air-Mate ${ }^{\mathrm{TM}}$, and MAXAIR CAPR 710) to a N-95, surgical N-95 and surgical mask. The experiments were conducted in a small room with no ventilation, under two conditions, door open and door closed. Each experiment was replicated five times per condition, for a total of ten replications per respirator and surgical mask. Data was collected using a colony forming unit (CFU) count from agar plates placed in the testing room. Results showed that all respirators and the surgical mask resulted in a contamination compared to an empty room, but showed significantly less contamination compared to an unprotected subject. All respirators tested generated a lower mean CFU than the surgical mask, and all the PAPRs tested showed less CFU than the surgical N-95. The MAXAIR and Air-Mate were concluded to not differ in mean CFU compared to the N-95, while the Versaflo showed a significant difference in mean CFU. It can be said the Air-Mate and MAXAIR may have the same contamination potential as a N-95, while the Versaflo showed the highest CFU out of all the PAPRs and most likely is not suited for use in a sterile environment. 


\section{Table of Contents}

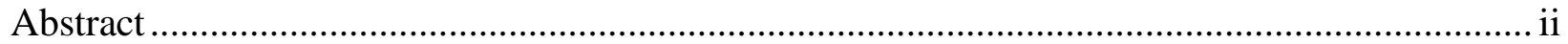

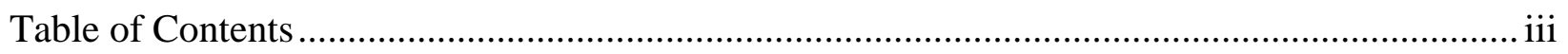

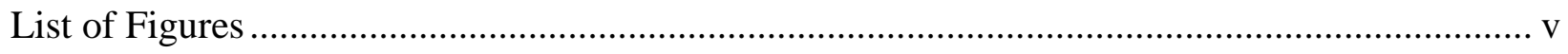

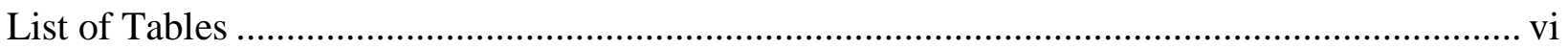

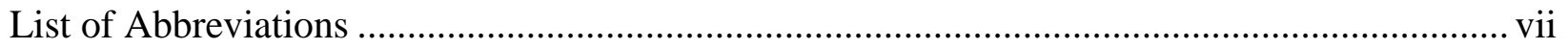

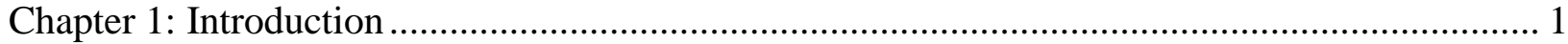

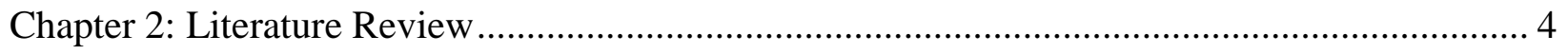

2.1 Respirator Use in Healthcare ................................................................................ 4

2.2 Contamination in an Operating Room ....................................................................... 4

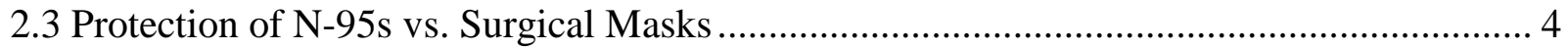

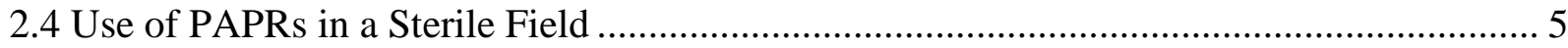

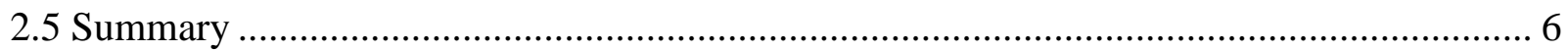

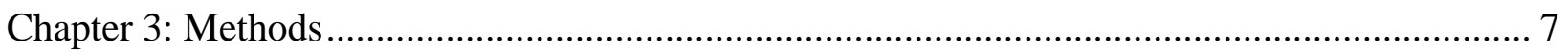

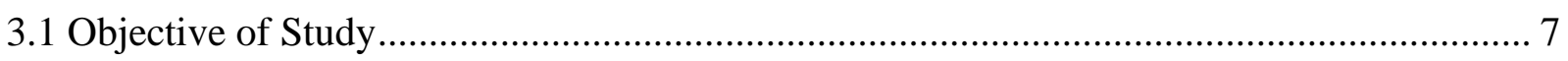

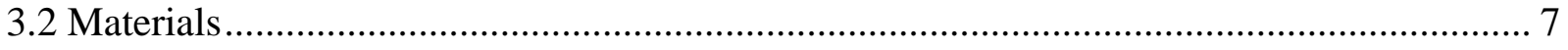

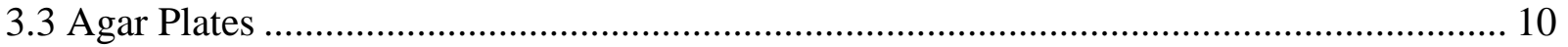

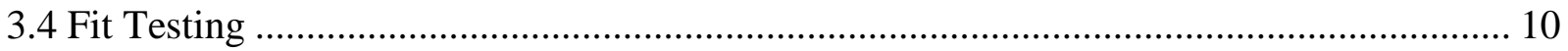

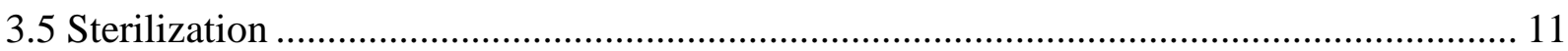

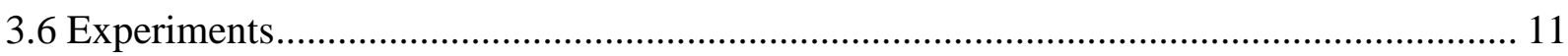

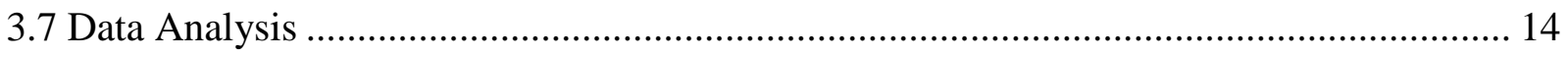

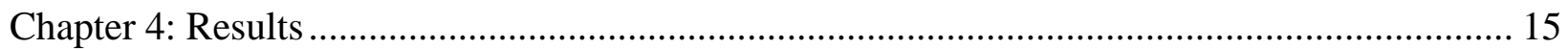

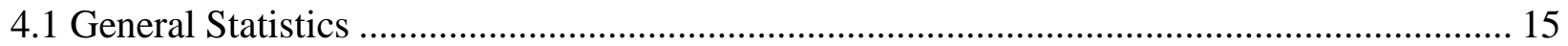

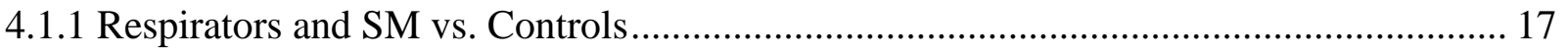

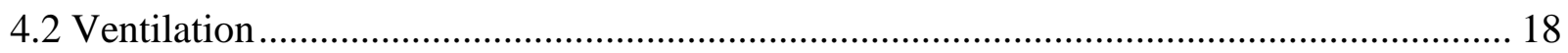

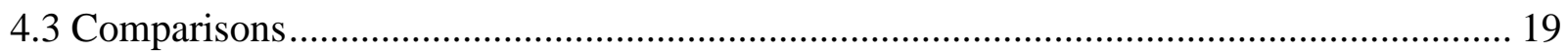

4.4 Plates on "Surgical Table” vs. Plates on Back Table ................................................. 23

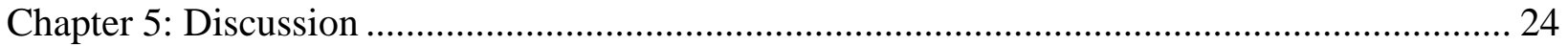

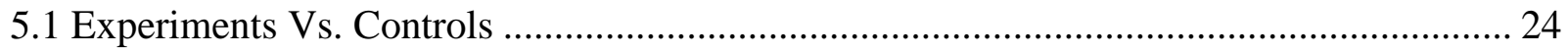

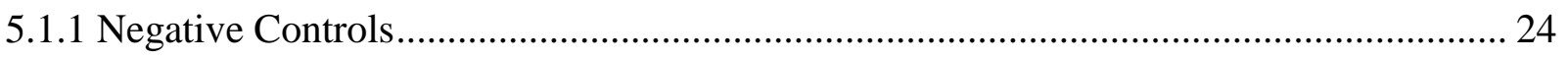

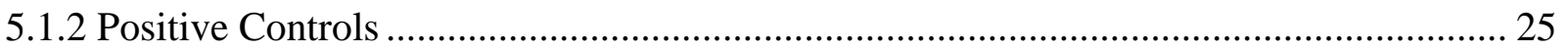


5.2 Effect of Ambient Air Exchange .................................................................................. 26

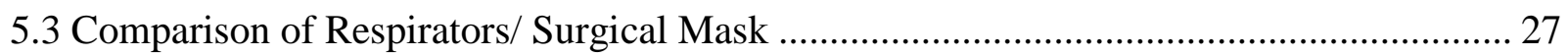

5.3.1 Respirators to Surgical Masks ...................................................................................... 27

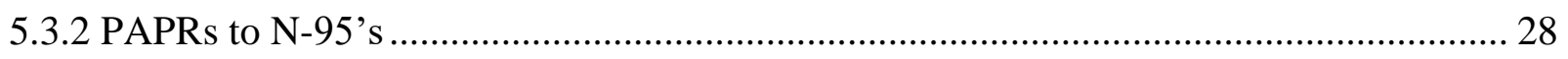

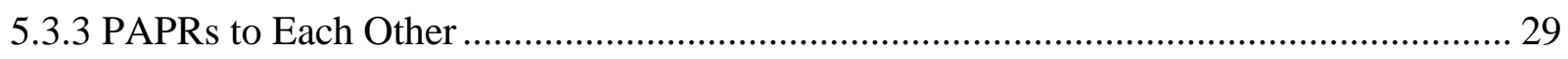

5.4 Plates on "Surgical Table" vs. Plates on Back Table ....................................................... 29

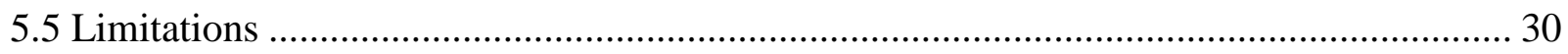

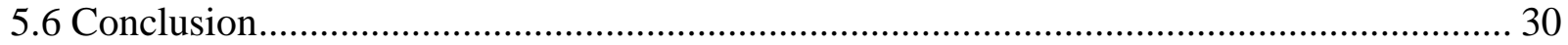

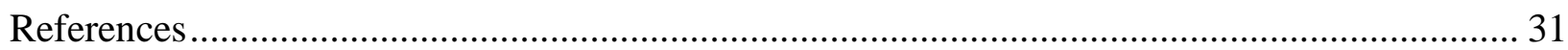

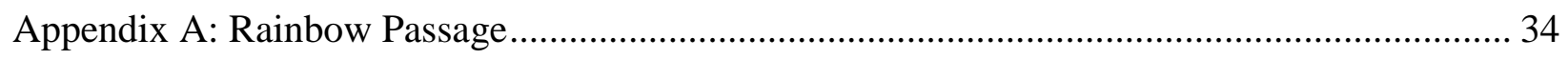

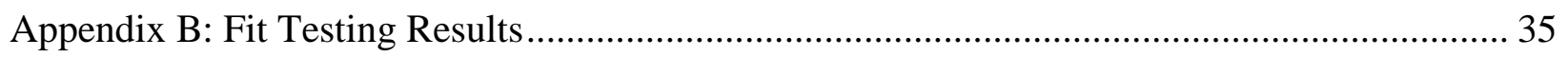

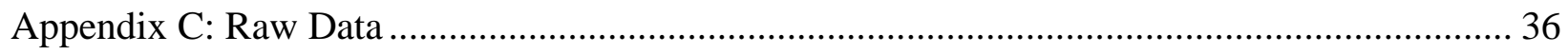

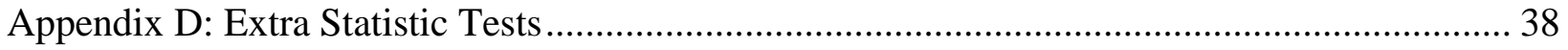




\section{List of Figures}

Figure 1: A) Surgical Mask B) N-95 .............................................................................. 1

Figure 2: Powered Air Purifying Respirator (PAPR) Example ............................................ 2

Figure 3: Subject Wearing Versaflo PAPR A) Front B) Back .............................................. 8

Figure 4: Subject Wearing Air-Mate PAPR A) Front B) Back ................................................ 8

Figure 5: Subject Wearing MAXAIR PAPR A) Front B) Back ............................................. 9

Figure 6: A) N-95 B) Surgical N-95 C) Surgical Mask........................................................ 9

Figure 7: Testing Chamber with Placements of the Controls ................................................ 13

Figure 8: Testing Chamber with Placement of the Testing Plates ........................................... 13

Figure 9: Mean CFU for each Respirator/SM.................................................................. 16 


\section{List of Tables}

Table 1: Mean CFU per Plate for Respirators and Surgical Mask ........................................... 15

Table 2: Respirators and SM vs. Negative Control (-) and Positive control (+), Alpha 0.05 ...... 17

Table 3: Door Open vs. Door Closed, Alpha 0.05 .............................................................. 18

Table 4: Respirators Compared to Surgical Masks, Alpha 0.05 ................................................ 19

Table 5: PAPRs Compares to N-95's, Alpha 0.05 …............................................................. 19

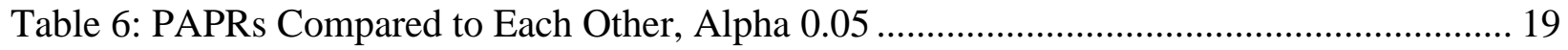

Table 7: Difference in Plate Location for Respirators vs. Surgical Masks............................... 20

Table 8: Difference in Plate Location for PAPRS vs. Surgical N-95 ..................................... 21

Table 9: Comparison of Plates on Two Different Tables, Alpha 0.05 ................................... 23 


\section{List of Abbreviations}

$\begin{array}{cc}\text { APF } & \text { Assigned protection factor } \\ \text { CDC } & \text { Center for Disease Control } \\ \text { CFU } & \text { Colony forming unit } \\ \text { FDA } & \text { Food and Drug Administration } \\ \mathrm{H}_{\mathrm{A}} & \text { Alternate hypothesis } \\ \mathrm{H}_{0} & \text { Null hypothesis } \\ \text { NIOSH } & \text { National Institute of Occupational Safety and Health } \\ \text { OR } & \text { Operating room } \\ \text { OSHA } & \text { Occupationally Safety and Health Administration } \\ \text { PAPR } & \text { Powered air-purifying respirator } \\ \text { SM } & \text { Surgical mask } \\ \text { STD } & \text { Standard deviation }\end{array}$




\section{Chapter 1: Introduction}

Respiratory protection in an operating room (OR) has two main objectives; protecting the patient from infection by the surgical team and protecting the surgical team from infection and aerosols generated during surgery. For the first objective, protecting patients, surgical masks are commonly used. Surgical masks are not classified as a respirator but as a medical device, thus needing to be approved by the Food and Drug Administration (FDA) (FDA, 2018). These masks cover the nose and mouth of the user and act as a barrier to guard against droplets contacting the patient. The barrier provided protects the wearer from body fluids, however the user may still be at a significant risk for inhaling small particles and bacteria. To better satisfy both key objections, a N-95 can be used in place of a surgical mask.
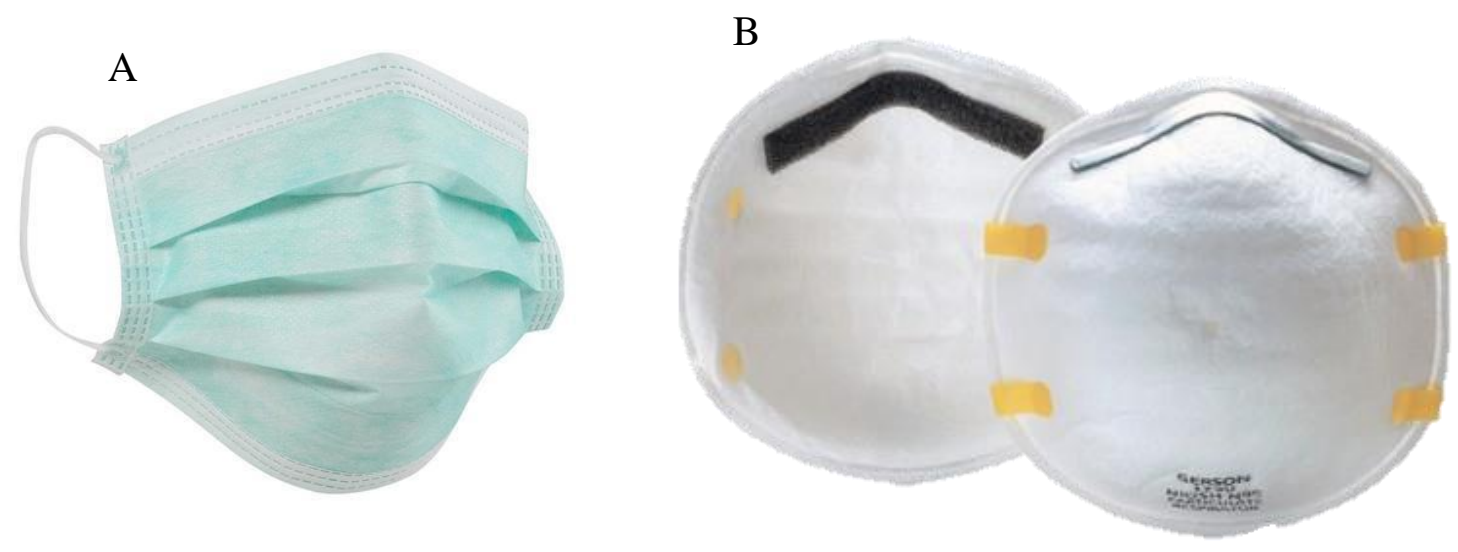

Figure 1: A) Surgical Mask B) N-95

A N-95 and surgical mask appear similar, as shown in Figure 1, however a N-95 is classified as a respirator and protects the user from smaller inhalable particles. To ensure the respirator functions as intended, they are tested and approved by the National Institute for Occupational Safety and Health (NIOSH) to be at least $95 \%$ effective at removing particles from the air (CDC-NIOSH, 2018). An assigned protection factor (APF) of 10 is given to a half mask N95 , meaning that only $1 / 10$ of contaminates in the air will leak into the mask (OSHA, 2009). The 
Occupational Safety and Health Administration (OSHA) recommends the use of a N-95 during aerosol generating procedures in a healthcare facility (OSHA, 2015). A N-95 can be worn in place of a surgical mask, however to be used in a surgical setting approval must be gained from the FDA (FDA, 2018). Unlike the surgical mask, which can be worn by anyone, the N-95 is required to be fit tested annually to provide proper protection, which can be costly and time consuming for a health care facility (Liverman et al., 2015). In addition to time and cost, health care workers who are properly fit tested and trained on using a N-95 may still be reluctant to wear them. Common complains about wearing a N-95 include, moisture build up, difficulty breath, trouble communicating, and the potential of scaring patients due to the covering of the face.
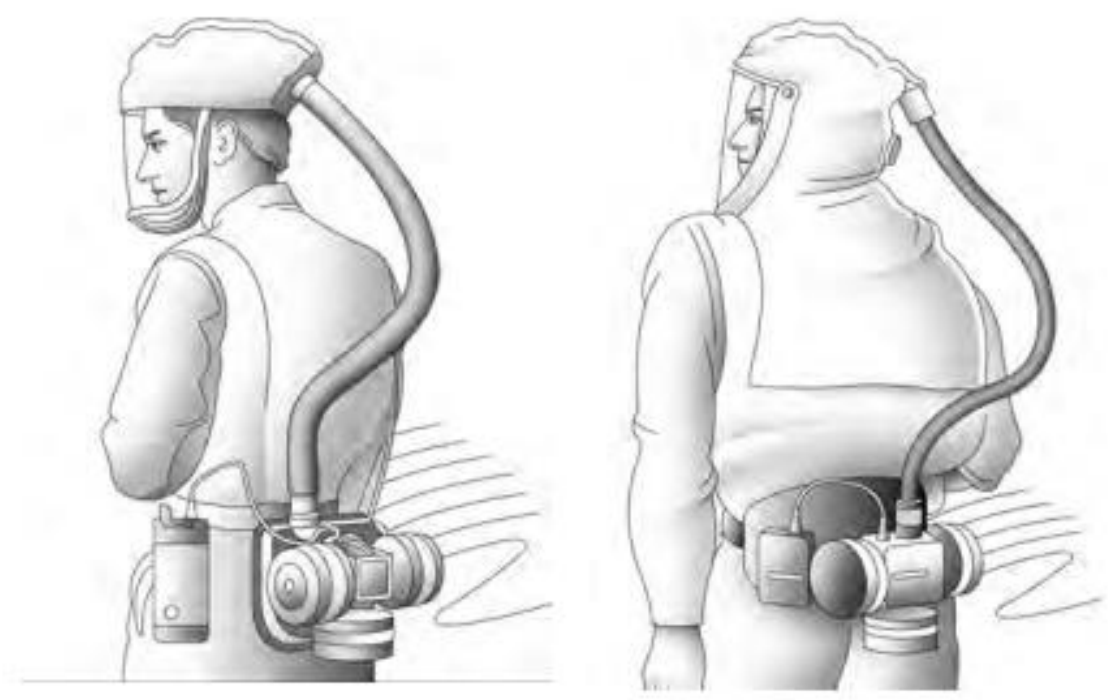

Figure 2: Powered Air Purifying Respirator (PAPR) Example

A potential solution to the complaints against the N-95 is wearing a loose-fitting powered air purify respirator (PAPR). A PAPR consists of a fan that intakes air and passes it through a filter, then into a helmet/head piece worn by the user. An example can be seen in Figure 2. PAPR's have a higher degree of protection than a N-95, with an APF of 25 and the potential of 1,000 if substantial evidence is documented (OSHA, 2009). The increase in protection is due to high efficiently filters and utilizing positive pressure, meaning air is always blowing into the hood or helmet of the wearer (OSHA, 2015). Loose fitting PAPRs, unlike a N-95, do not need to be fit tested to provide adequate protection, hence one of their draws. In addition, the constant airflow provides a cooling effect on the user, the clear face shield will allow patients to see the workers 
face, and they are reusable (Liverman et al., 2015). Despite the added benefits PAPRs are less common, mainly due to their average initial cost of $\$ 768.20$ vs. $\$ 1.50$ for an N-95 (Liverman, et al., 2015). Added complaints include, interference with communication and mobility, required maintenance, and cleaning of the device. OSHA primarily recommends the use of PAPRs for hospital first responders and in the event of a large-scale disaster or for an unknown biological or chemical threat (OSHA, 2015). Regarding an OR, OSHA does not currently recommend the use of loose-fitting PAPRS, due to fear of contamination of the sterile field (OSHA 2015). There is a lack of data about PAPRs in an OR, but the main worry is the exhaust from the PAPR could contaminate the sterile field of the OR. Unlike a N-95 or surgical mask there is no filter for the air exhaled from the user to pass through before returning to the room. This lack of barrier may result in the exhaled air carrying aerosolized bacteria into the sterile field and risking the patient's safety. However, this is speculation as there is not enough data to determine the risk of using a PAPR in an OR, hence this study.

The purpose of this study is to be a preliminary test to determine how the generation of bacteria from a user wearing a loose-fitting PAPR compares to that of commonly used protection devices such as a surgical mask and a N-95. This study will test three PAPR models and compare bacteria generation to an N-95, N-95 approved to be used in an OR, and surgical mask. The results may help shed light on how these PAPRs preform in a sterile field and if they could be used in a OR. 


\section{Chapter 2: Literature Review}

\subsection{Respirator Use in Healthcare}

A study from Wizner, et al. addressed respiratory protective devices prevalence in U.S. health care facilities. The study involved a survey disrupted to professional nursing society members in 2014 and 2015. In the survey the questions were asked about how often N-95 and PAPRs were used by the nurses and what models they have used. The most common types of respirators used were N-95's with 95\% of nurses having used one in the last year and PAPR's with $78 \%$ of nurses having used one (Wizner, et al., 2016). The most common models of PAPRs included $3 \mathrm{M}^{\mathrm{TM}}$ Air-Mate ${ }^{\mathrm{TM}}$ (50\% of responses), $3 \mathrm{M}^{\mathrm{TM}}$ Versaflo ${ }^{\mathrm{TM}}$ (10\% of responses), and the Syntech International MAXAIR (23\% of responses). For N-95's a total of 27 different models were reported being used with the most common being from $3 \mathrm{M}^{\mathrm{TM}}$ (70\% of responses) and Kimberly-Clark ${ }^{\mathrm{TM}}$ (Wizner et al., 2016).

\subsection{Contamination in an Operating Room}

Operating rooms are considered a sterile environment, void of bacteria life, however whenever humans enter the field for what ever reason, the potential for contamination and infection increases. A study by Edmiston et al. evaluated microbial contamination in an operating room by means of air sampling. The study found coagulase-negative staphylococci in $51 \%$ of air samples and staphylococcus aureus in $36 \%$ of air samples, within a half meter of the wound (Edmiston et al., 2005). Another study by Zhiqing et al. sought to determine how much contamination was present on a surgical mask after being worn. The study compares a surgical mask worn during procedures of varying lengths, to that of a mask just sit in an empty operating room. The bacteria levels were significantly higher for the worn mask compared to the unused mask, while the bacteria levels increased with time starting at the two-hour time frame (Zhiqing et al., 2018). The study recommends the changing of surgical masks at this point to help reduce the chance for infection.

\subsection{Protection of N-95s vs. Surgical Masks}

Currently the two most common protective devices worn over the mouth and nose in an operating room (OR) are surgical masks and N-95's. As such there have numerous studies comparing the two to determine which is more effective at preventing infection in health care 
workers. Lee et al. compared the N-95 and surgical filter efficiency by using $\mathrm{NaCl}$ aerosol particles to represent bacteria. Using human subjects four N-95's and three surgical masks were fit tested, and it was shown that $29 \%$ of the N-95s hand a protection factor less than 10 while $100 \%$ of the surgical masks had protection factor less than 10 (Lee et al, 2008). Another study, Smith et al, evaluated 6 clinical studies and 23 surrogate exposure studies to determine if surgical masks or N95's protected health care workers more effectivity. Form the study they showed that in a laboratory setting the N-95 showed a protective advantage over surgical masks (Smith et al., 2016). In addition, in the exposure studies N-95s were associated with less filter penetration and less leakage than surgical masks (Smith et al., 2016). Balazy et al. compared two N-95 respirators to two surgical masks against a biological airborne virus. In the study both surgical masks showed a higher penetration than the N-95s did (Balazy et al., 2006). It is also interesting to note that the N95 did exceed a penetration level of 5\% in some occasions. (Balazy et al., 2006).

\subsection{Use of PAPRs in a Sterile Field}

There is little data to draw conclusions about the PAPR's use in a sterile environment. Previously the University of Cincinnati conducted a similar study comparing an N-95 to a PAPR (Grinshpun). The PAPR used in the study had a 3M BE-12-3 white respirator head cover, the same sample model which was used for one of the PAPRs selected for this experiment. The study used two subjects wearing identical respirators, in a simulated OR. To collect the bacteria samples, agar plates were used and a colony forming unit (CFU) was counted. Collected data was compared to a control of an empty room, resulting in no significant different in CFU between the N-95 and the control, while the PAPR produced a significantly higher CFU than the control (Grinshpun). From these results it was concluded that the PAPR did result in an over contamination of the sterile field. In addition, it was concluded that there was no specific agar plate location that had a higher amount of CFU (Grinshpun).

A study by Kim et al. involved determining if the number of particles in the air increased when a helmet PAPR was being used in an OR. The study concluded that wearing the helmet PAPR did not increase the particle count around the operating table in the OR (Kim et al., 2017). 


\subsection{Summary}

In the literature it was shown that there is potential for contamination in an operating room even through a surgical mask is worn. In addition, extended surgery times may result in a higher accumulation of bacteria around the mask and lead to an increased risk of infection. When comparing N-95's to surgical masks it appears the N-95 is more protective than a surgical mask, however some literature seems to disagree concluding no difference in infection rates between surgical masks and N-95's.

Currently N-95s are more commonly used in a health care setting, but PAPRs have shown use as well. However, there is little literature present about the use of PAPRs in a sterile operating room environment of which N-95's and surgical masks are commonly used. The only previous study showed an overall contamination of a sterile field when using a PAPR. 


\section{Chapter 3: Methods}

\subsection{Objective of Study}

The objective of the study was to compare the bacterial generation of a user wearing three different models of loose-fitting PAPRs to wearing an N-95, surgical N-95, and a surgical mask. A colony forming unit (CFU) of bacteria on agar plates was used to compare each model PAPR to the N-95, Surgical N-95, and surgical mask. Negative controls were taken of an empty room and positive controls were taken of the subject wearing no respirator or surgical mask. In addition, the effect of ambient air exchange vs. no ventilation was compared for each experimental device. Lastly, a location effect will be investigated for any significant results to determine what location if any the difference can be attributed to.

\subsection{Materials}

- $\quad 3 \mathrm{M}^{\mathrm{TM}}$ Versaflo $^{\mathrm{TM}}$ TR-600-ECK PAPR with a $3 \mathrm{M}^{\mathrm{TM}}$ Versaflo $^{\mathrm{TM}} \mathrm{S}-433 \mathrm{~L}$ Hood (Referred to as Versaflo, Figure 3)

- $\quad 3 \mathrm{M}^{\mathrm{TM}}$ Air-Mate ${ }^{\mathrm{TM}}$ HEPA Belt-Mounted PAPR with a 3M BE-12 Hood (Referend to as Air-Mate, Figure 4)

- MAXAIR CAPR 710 System with DLC-Double Shroud (Referred to as MAXAIR, Figure 5)

- N-95 from Gerson (Referred to as N-95, Figure 6A)

- N-95/Surgical Mask 1512 from MOLDEX (Referred to as Surgical N-95, Figure 6 B)

- Surgical Mask from $3 \mathrm{M}^{\mathrm{TM}}$ (Referred to as Surgical Mask, Figure 6C)

- Tryptic Soy Agar from SIGMA-ALDRICH

- Sterilized Petri Dishes from Kord-Valmark

- $99.9 \%$ Isopropyl Alcohol from Fisher Chemical

- PortaCount Pro+ from TSI 

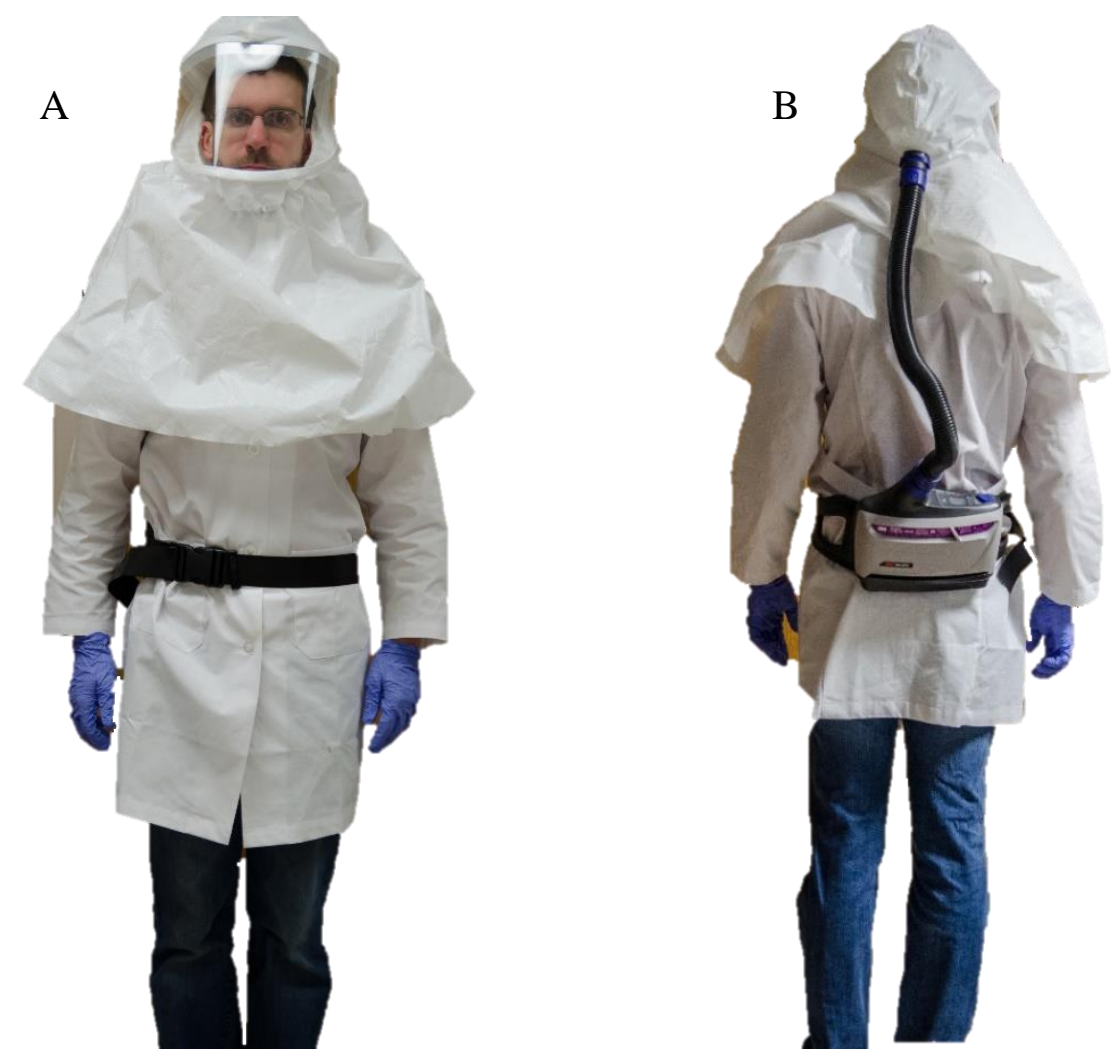

Figure 3: Subject Wearing Versaflo PAPR A) Front B) Back
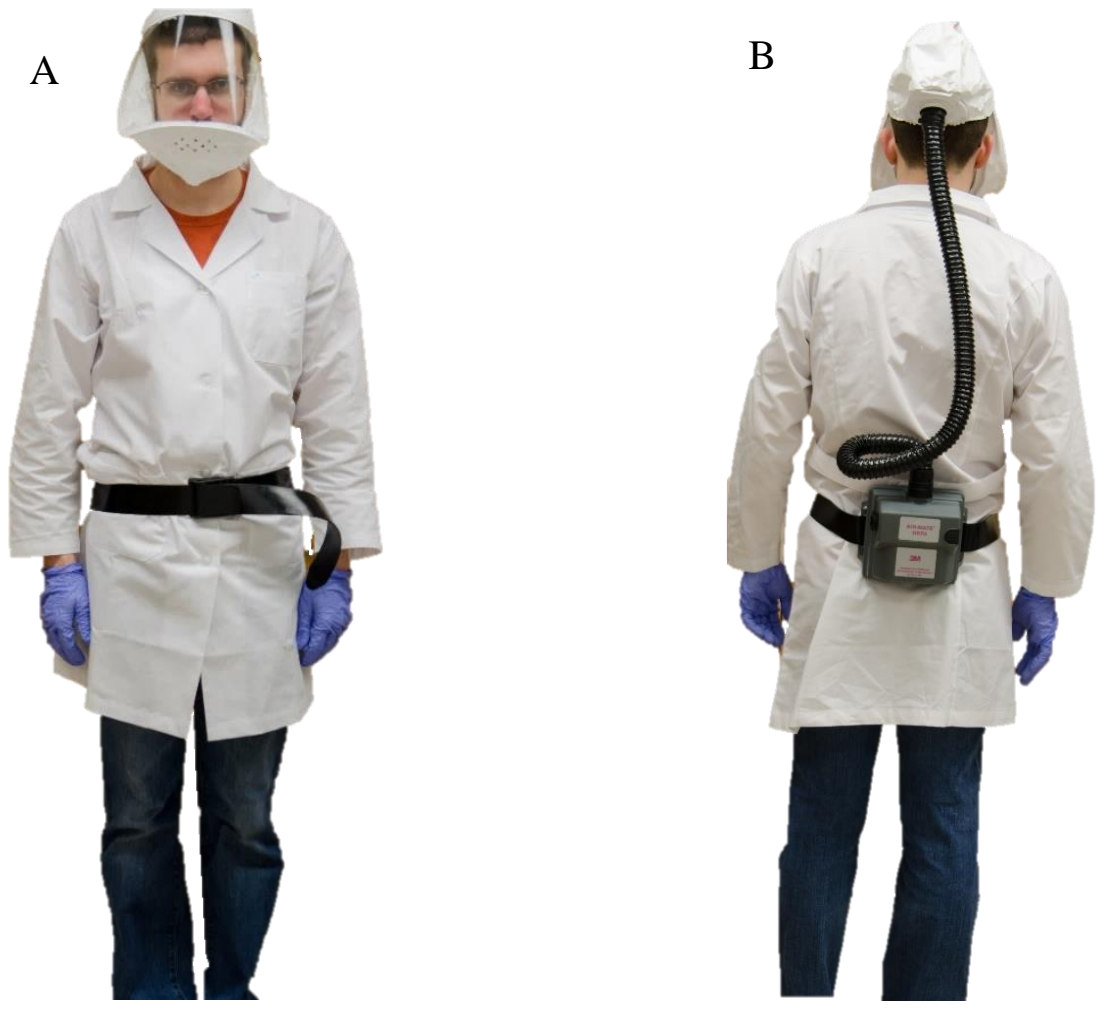

Figure 4: Subject Wearing Air-Mate PAPR A) Front B) Back 


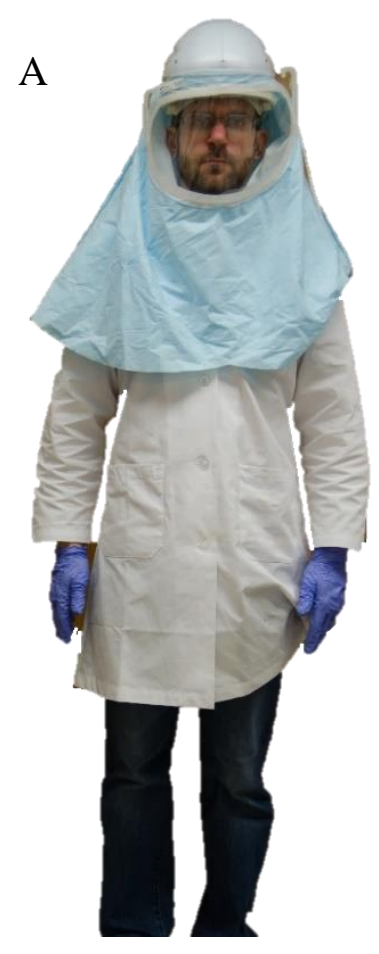

B

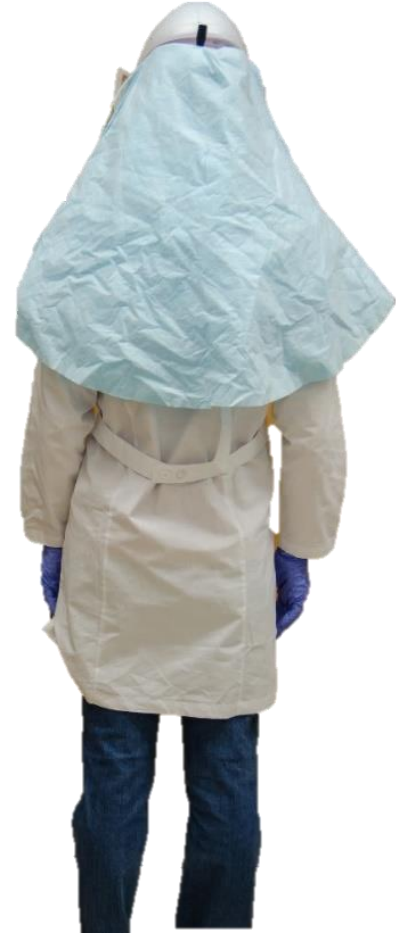

Figure 5: Subject Wearing MAXAIR PAPR A) Front B) Back

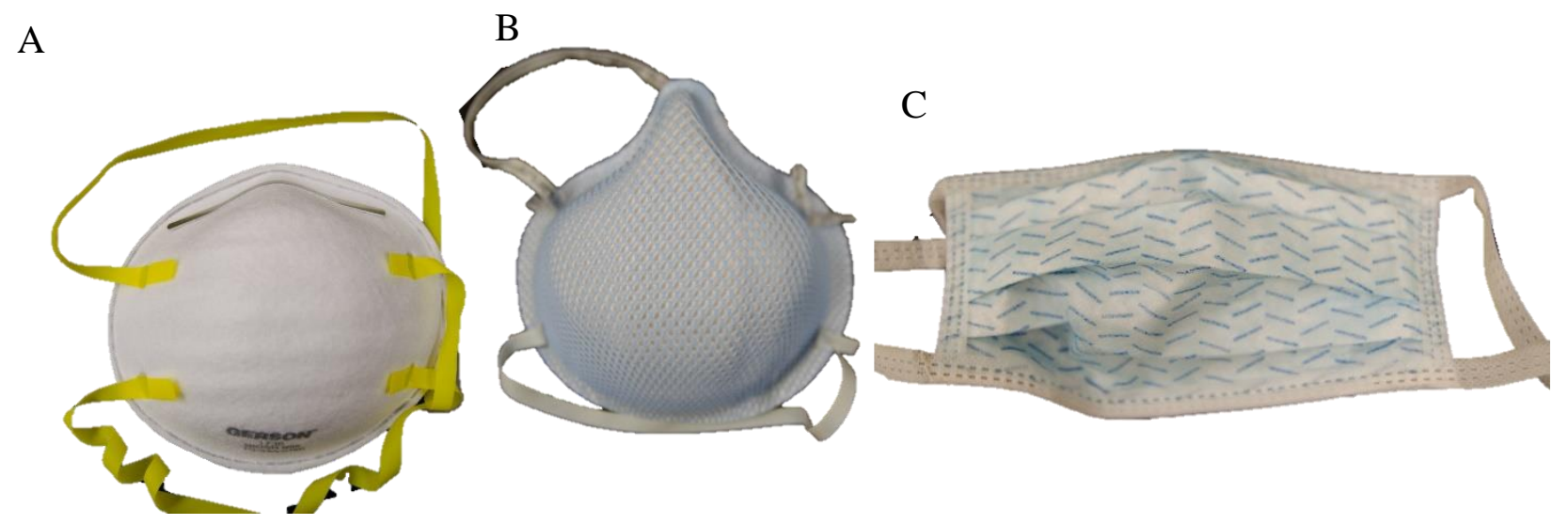

Figure 6: A) N-95 B) Surgical N-95 C) Surgical Mask 


\subsection{Agar Plates}

Agar plates were prepared in batches by mixing 10g of Tryptic Soy Agar in $250 \mathrm{ml}$ of deionized water under heat. After the agar was thoroughly dissolved, the mixture was autoclaved at $121 \mathrm{C}^{\circ}$ for 25 minutes. Autoclave tape was placed on each batch to ensure a proper sterilization temperature was reached during the autoclaving process. To ensure the agar's sterility was maintained, the pouring process was taken place in a laminar flow hood that had been cleaned and sterilized using 70\% isopropyl alcohol. The agar was poured into sterile petri dishes and allowed to cool and solidify. Once solid and cool, the plates were coved and stored in a refrigerator until needed.

As a quality control measure two plates were randomly chosen from each batch and incubated at $37^{\circ} \mathrm{C}$ for 24 hours to determine the sterility of the batch. If no bacteria grew, the batch was deemed sterile and able to use, but if any bacteria growth had occurred, the batch was disposed of.

\subsection{Fit Testing}

Prior to experimentation the subject had to be fit tested for both the N-95 and surgical N95. Fit testing was conducted using a Porta Count Pro+. Each N-95 had to be prepared with an inlet so that the PortaCount could measure the concentration of particles in the respirator. The respirator was deemed unfit for use after this process and was only used for fit testing. To generate particles to test the respirator against a $\mathrm{NaCl}$ solution was used in a particle generator. Once everything was hooked up correctly, the instructions on the PortaCount was fallowed and the tasks preformed are listed below.

- Normal breathing.

- Deep Breathing.

- Head side to side.

- Head up and down.

- Talking out load (rainbow passage Appendix A).

- Bending over.

- Normal breathing. 
The tests analyzed the concentration outside the N-95 with the concentration inside the N-95. For the N-95 models used, an overall fit factor of 100 must be achieved to pass. Both respirators tested on the subject passed the fit test and the data can be referred to in Appendix B.

\subsection{Sterilization}

Cleaning and sterilization of apparel, the testing room, and equipment was done with a $70 \%$ solution of isopropyl alcohol. The solution was diluted from a stock of $99.9 \%$ isopropyl alcohol to a more effective $70 \%$ concentration (CDC, 2016).

Before entering the testing room, proper precautions had to be taken as to not to introduce extra contamination to the room. To achieve this, gloves were worn over properly washed hands, along with a lab coat and long pants that covered the skin. All cloths were wiped down with $70 \%$ isopropyl alcohol prior to entering the chamber for any reason. When testing of a PAPR was being conducted, the respirator was thoroughly wiped down and sterilized with 70\% isopropyl alcohol solution. On the other hand, the N-95, surgical N-95 and surgical mask were used brand new every time and disposed of after use. In addition, whenever testing was not occurring and the room needed to be entered i.e. when placing controls or cleaning, a N-95 respirator was worn. The testing chamber was cleaned before every trial (consisting of a control then test). For the cleaning $70 \%$ isopropyl alcohol was used to wipe down the door, two tables, manikin, and walls.

\subsection{Experiments}

Trials were conducted in an enclosed $9 \mathrm{ft}$ by $11 \mathrm{ft}$ by $7.5 \mathrm{ft}$ room with no ventilation. In the room there were two tables, one for the simulated patient (manikin) and the other as a background table, as seen in Figure 7 and Figure 8. Due to the lack of ventilation each of the respirators were tested under two conditions, door closed (no air exchange) and door open (ambient air exchange, door being $2.5 \mathrm{ft}$ by $6.7 \mathrm{ft}$ ). The fallowing respirators and surgical mask were tested $3 \mathrm{M}^{\mathrm{TM}}$ Versaflo $^{\mathrm{TM}}$ TR-600-ECK PAPR with a $3 \mathrm{M}^{\mathrm{TM}}$ Versaflo $^{\mathrm{TM}} \mathrm{S}-433 \mathrm{~L}$ hood, $3 \mathrm{M}^{\mathrm{TM}}$ Air-Mate ${ }^{\mathrm{TM}}$ HEPA Belt-Mounted PAPR with a 3M BE-12 hood, MAXAIR CAPR 710 System with DLC-double shroud, N-95 from Gerson, surgical N-95 1512 from MOLDEX, and surgical mask from 3M ${ }^{\mathrm{TM}}$. In addition, a positive control was conducted with the subject wearing no respirator or surgical mask. Each experimental setup was duplicated five times, for a total of 64 trials ([6 [3 PAPRs, 1 
N-95, 1 surgical N-95, 1 surgical mask] X 2 conditions [door open/ door closed] X 5 replications] +4 positive controls). For all experiments one subject was used.

The order of trials was determined through a random number generator in excel. The first part of each trial involved a negative control, which was ran for one hour in the empty room, with the door in the appropriate position. The control consisted of four agar plates placed on the neck of the manikin, navel of the manikin, between the feet of the manikin, and on the back table as seen in Figure 7. As soon as one hour had passed the controls were coved and incubated at $37^{\circ} \mathrm{C}$ for 24 hours, and the experimental portion was started directly after.

For the experimental portion 16 agar plates were used, 2 being placed on the manikin (head and navel), 5 being placed on either side of the manikin (head, shoulder, elbow, thigh, and feet) and 4 at each corner of the back table, which can be seen in Figure 8. The plates were uncovered when the subject entered the room and covered when they left. Once wearing the proper respirator and undergoing the sterilization procedure, the subject entered the room and started the experimental portion of the trial. When starting the experiment, the subject was to stand opposite the door near the chest of the manikin (between plates 5 and 8). In the room the subject was to repeat a set of tasks over a one-hour period. Each set lasted five minutes and after every set the subject would rotate around the table from between plates 5 and 8 to between plates 6 and 7 , then back after another five minutes. The task set was as follows:

- Minutes 0-2: Read rainbow passage (Appendix A)

- Minutes 2-3: Rest

- Minutes 3-4: Chest compressions on manikin

- Minutes 4-5: Rest

After the one hour had passed the plates were coved and incubated at $37^{\circ} \mathrm{C}$ for 24 hours. After 24 hours a CFU was counted for each plate. 


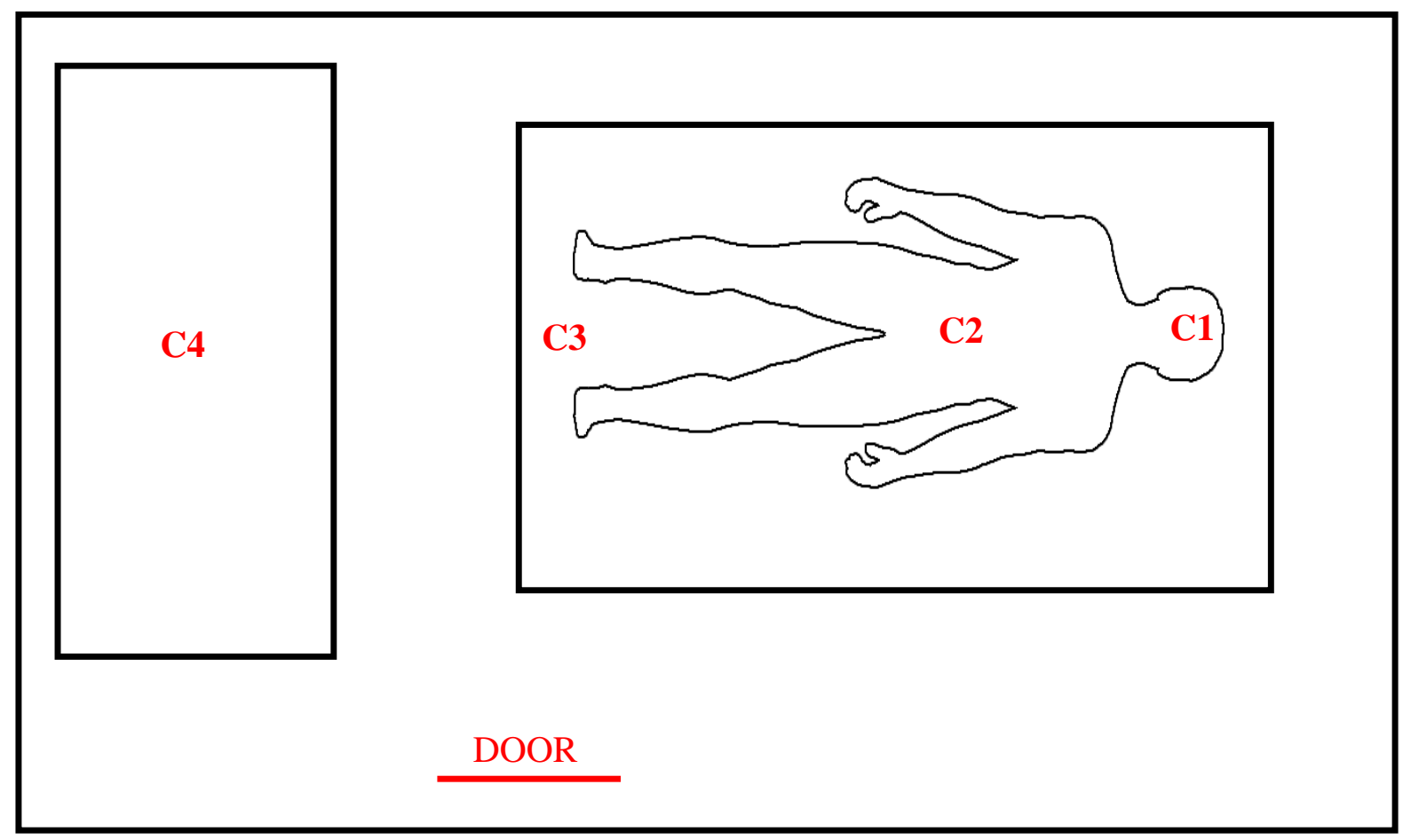

Figure 7: Testing Chamber with Placements of the Controls

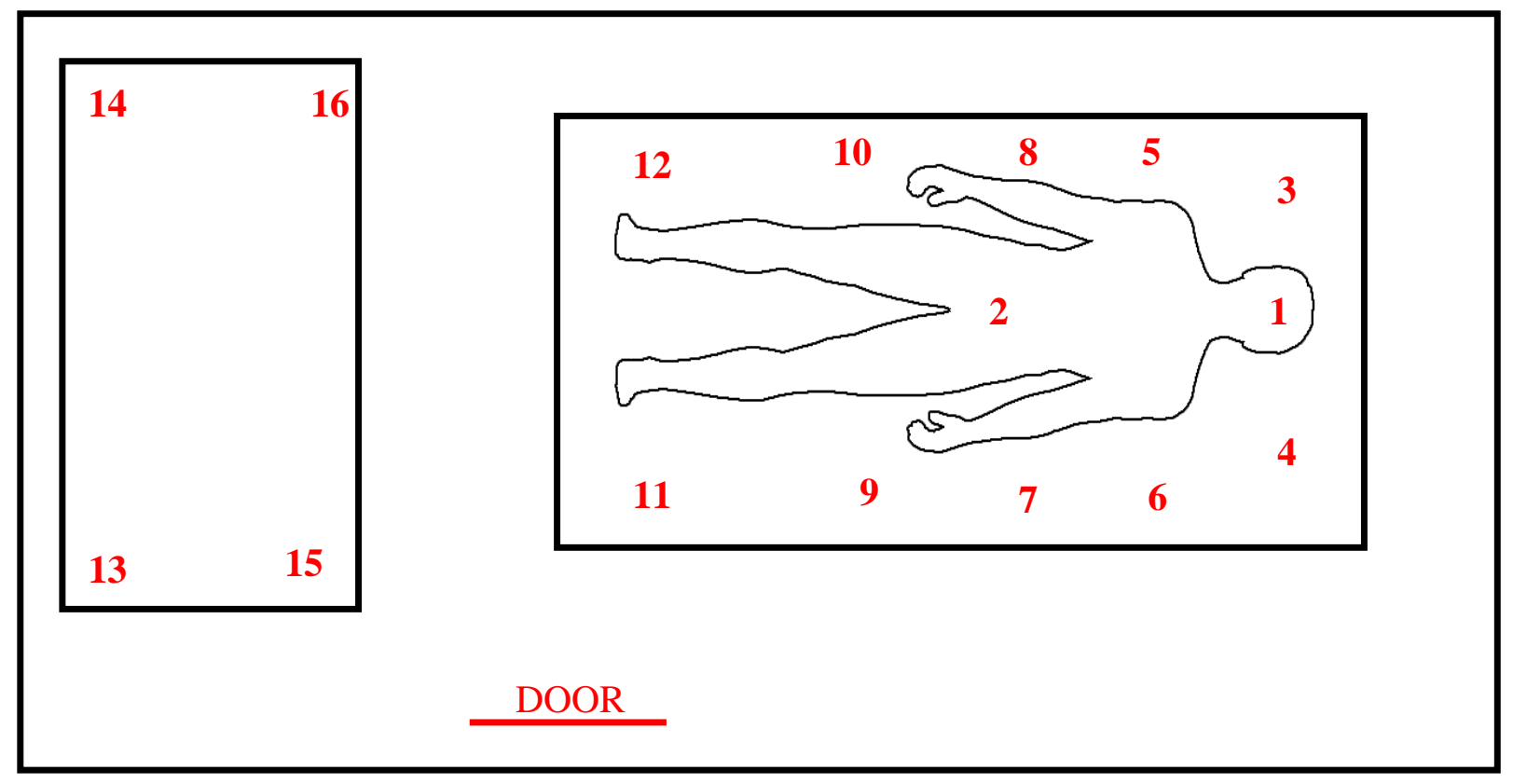

Figure 8: Testing Chamber with Placement of the Testing Plates 


\subsection{Data Analysis}

For data analysis, all five replicates for each combination (respirator or surgical mask, door open or closed) was averaged together to obtain one data set for said combination i.e. all five plate 1 's for a given combination was averaged and that was the overall plate 1 for that combination. This process was completed for each of the 20 plates per combination ( 4 control, 16 experimental) to obtain a more accurate data set. The raw data can be referenced in Appendix C.

When comparing the respirators/SM to each other, both conditions (door open/close) were averaged into a pooled data set for the single respirator in a similar manner, thus 10 data points per plate for each respirator/SM instead of 5. Both the mean and standard deviation (STD) were calculated from the pooled data for each respirator/SM. To compare various aspects of the study t-tests were used, the specifics which will be discussed in the fallowing results section. 


\section{Chapter 4: Results}

\subsection{General Statistics}

Table 1: Mean CFU per Plate for Respirators and Surgical Mask

\begin{tabular}{ccccccc}
\hline $\begin{array}{c}\text { Plate } \\
\text { Number }\end{array}$ & Versaflo & Air-Mate & MAXAIR & N-95 & $\begin{array}{c}\text { Surgical } \\
\text { N-95 }\end{array}$ & $\begin{array}{c}\text { Surgical } \\
\text { Mask }\end{array}$ \\
\hline $\mathbf{1}$ & 4.0 & 3.4 & 2.3 & 2.4 & 4.1 & 4.7 \\
\hline $\mathbf{2}$ & 2.2 & 2.0 & 2.8 & 1.9 & 4.2 & 4.4 \\
\hline $\mathbf{3}$ & 3.0 & 1.8 & 3.1 & 2.4 & 3.1 & 5.1 \\
$\mathbf{4}$ & 2.8 & 2.2 & 2.3 & 2.9 & 4.3 & 4.5 \\
\hline $\mathbf{5}$ & 2.4 & 2.3 & 1.3 & 2.5 & 5.3 & 6.4 \\
\hline $\mathbf{6}$ & 4.7 & 2.3 & 3.1 & 2.5 & 5.1 & 6.0 \\
\hline $\mathbf{7}$ & 3.1 & 2.1 & 2.5 & 2.8 & 4.2 & 5.7 \\
\hline $\mathbf{8}$ & 3.2 & 2.9 & 3.0 & 1.7 & 4.0 & 5.8 \\
\hline $\mathbf{9}$ & 2.3 & 2.3 & 1.8 & 1.6 & 2.5 & 4.0 \\
\hline $\mathbf{1 0}$ & 1.5 & 1.7 & 2.9 & 1.8 & 3.1 & 4.2 \\
\hline $\mathbf{1 1}$ & 2.2 & 1.7 & 1.9 & 1.2 & 2.9 & 3.8 \\
\hline $\mathbf{1 2}$ & 2.1 & 1.6 & 1.6 & 1.6 & 3.5 & 3.3 \\
\hline $\mathbf{1 3}$ & 1.3 & 1.0 & 1.5 & 1.2 & 2.0 & 2.3 \\
\hline $\mathbf{1 4}$ & 2.4 & 1.3 & 0.8 & 1.3 & 1.2 & 2.3 \\
\hline $\mathbf{1 5}$ & 2.5 & 1.2 & 1.7 & 1.0 & 1.3 & 2.0 \\
\hline $\mathbf{1 6}$ & 1.0 & 1.4 & 1.6 & 1.0 & 1.1 & 1.4 \\
\hline Mean & 2.54 & 1.95 & 2.14 & 1.93 & 3.24 & 4.12 \\
\hline STD & 0.94 & 0.83 & 0.83 & 0.80 & 1.34 & 1.53 \\
\hline
\end{tabular}
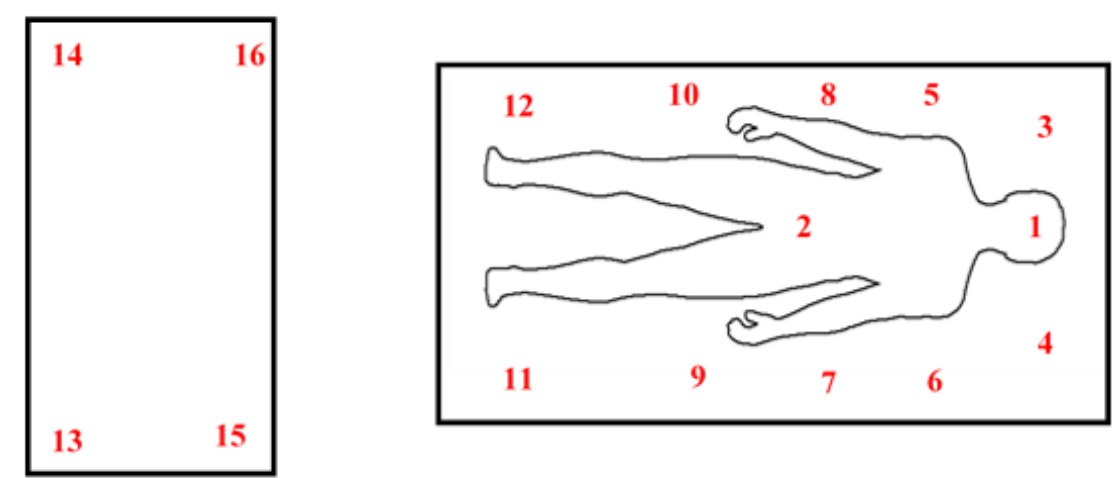


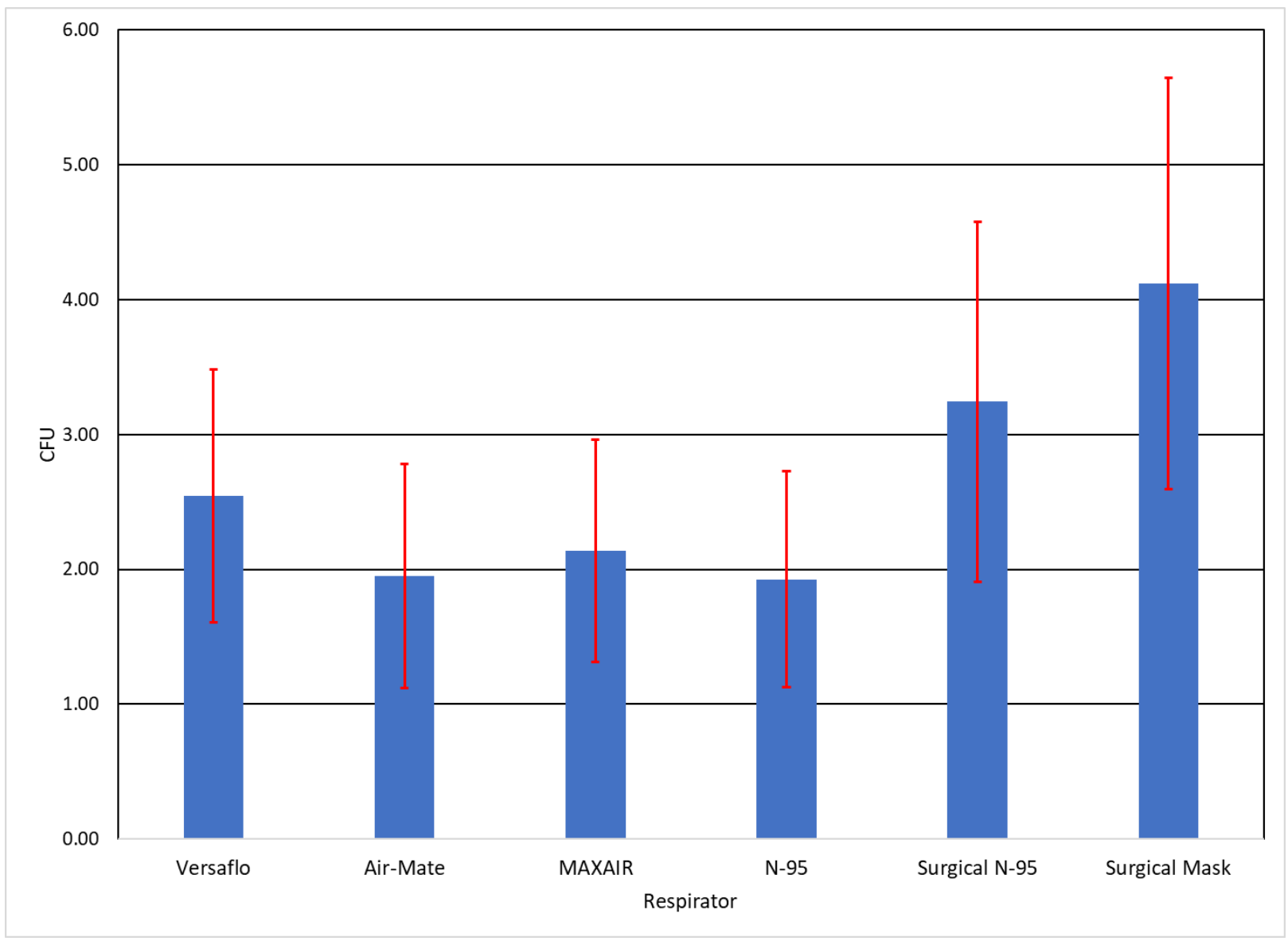

Figure 9: Mean CFU for each Respirator/SM

Table 1 displays the average plate CFU per plate location (10 plates per location), mean, and standard deviation (STD) for each respirator and surgical mask. Figure 9, represents the overall CFU per plate across all trials. Figure 10 displays the mean CFU of the respirators and surgical mask used. 


\subsubsection{Respirators and SM vs. Controls}

Table 2: Respirators and SM vs. Negative Control (-) and Positive control (+), Alpha 0.05

Respirator Control Control Experimental Experimental Pvalue Significant CFU STD CFU $\quad$ STD

\begin{tabular}{|c|c|c|c|c|c|c|}
\hline Versaflo - & 0.70 & 0.35 & 2.54 & 0.94 & 0.0014 & YES \\
\hline Versaflo + & 25.9 & 2.5 & 2.54 & 0.94 & 0.0002 & YES \\
\hline Air-Mate - & 0.90 & 0.29 & 1.95 & 0.63 & 0.0049 & YES \\
\hline Air-Mate + & 25.9 & 2.5 & 1.95 & 0.83 & 0.0001 & YES \\
\hline MAXAIR - & 0.65 & 0.17 & 2.14 & 0.71 & 0.0073 & YES \\
\hline MAXAIR + & 25.9 & 2.5 & 2.14 & 0.83 & 0.0002 & YES \\
\hline N-95 - & 0.83 & 0.29 & 1.93 & 0.69 & 0.0068 & YES \\
\hline N-95 + & 25.9 & 2.5 & 1.93 & 0.80 & 0.0001 & YES \\
\hline Surgical N-95 - & 0.65 & 0.06 & 3.24 & 1.34 & 0.0013 & YES \\
\hline Surgical N-95 + & 25.9 & 2.5 & 3.24 & 1.34 & 0.0028 & YES \\
\hline Surgical Mask - & 0.93 & 0.50 & 4.12 & 1.53 & 0.0007 & YES \\
\hline Surgical Mask + & 25.9 & 2.5 & 4.12 & 1.53 & 0.0004 & YES \\
\hline
\end{tabular}

In Table 2, CFU is the mean number of bacteria colonies observed for all plates in the negative control (empty room), positive control (subject not wearing a respirator) and experimental setup (subject in the room wearing a respirator or surgical mask).

The p-values were obtained by using a two-sample t-test, assuming equal variances, at an alpha level of 0.05 . For the negative controls the null hypothesis $\left(\mathrm{H}_{0}\right)$ was stated that there is no difference in the mean CFU between an empty room, and the when the subject was present in the room wearing a respirator or SM. The alternative hypothesis $\left(\mathrm{H}_{\mathrm{A}}\right)$ was stated that the mean $\mathrm{CFU}$ of the empty room would be different, then the mean $\mathrm{CFU}$ when the subject was wearing a 
respirator or surgical mask in the room. For the positive controls $\mathrm{H}_{0}$ is described as no difference between the mean CFU when the subject was not wearing a respirator or surgical mask compared to when a respirator or surgical mask was worn. The $\mathrm{H}_{\mathrm{A}}$ is stated that not wearing a respirator or surgical mask will result in a different mean CFU compared to wearing a respirator or surgical mask.

- $\mathrm{H}_{0}: \mathrm{CFU}$ negative control mean $=\mathrm{CFU}$ experimental mean

- $\mathrm{H}_{\mathrm{A}}: \mathrm{CFU}$ negative control mean $\neq \mathrm{CFU}$ experimental mean

- $\mathrm{H}_{0}: \mathrm{CFU}$ positive control mean $=\mathrm{CFU}$ experimental mean

- $\mathrm{H}_{\mathrm{A}}: \mathrm{CFU}$ positive control mean $\neq \mathrm{CFU}$ experimental mean

In this case a significant result $(\mathrm{p}<0.05)$ indicates that the experimental portion presented with a different mean CFU than the negative control or the positive control. A non-significant result ( $\mathrm{p}>$ 0.05) would conclude that there is no difference in the mean CFU for the negative or positive controls compared to the experimental portion.

\subsection{Ventilation}

Table 3: Door Open vs. Door Closed, Alpha 0.05

\begin{tabular}{ccccccc}
\hline Respirator & $\begin{array}{c}\text { Open } \\
\text { CFU }\end{array}$ & $\begin{array}{c}\text { Open } \\
\text { STD }\end{array}$ & $\begin{array}{c}\text { Closed } \\
\text { CFU }\end{array}$ & $\begin{array}{c}\text { Closed } \\
\text { STD }\end{array}$ & P-Value & Significant \\
\hline Versaflo & 2.21 & 0.90 & 2.88 & 1.15 & 0.0801 & NO \\
\hline Air-Mate & 1.56 & 0.75 & 2.34 & 0.74 & 0.0060 & YES \\
\hline MAXAIR & 1.93 & 0.68 & 2.35 & 0.92 & 0.1485 & NO \\
\hline N-95 & 1.81 & 0.76 & 2.04 & 0.85 & 0.4360 & NO \\
\hline Surgical N-95 & 2.78 & 1.28 & 3.71 & 1.62 & 0.0677 & NO \\
\hline Surgical Mask & 3.55 & 1.53 & 4.69 & 1.85 & 0.0793 & NO
\end{tabular}

In Table 3 above the p-value was obtained using a two-sample t-test, assuming equal variance, at an alpha level of 0.05. The Ho was stated as no difference in the mean CFU between 
the door being open and being close. The Ha was stated as the door being closed would result in a higher mean CFU count than the door being open.

- $\mathrm{H}_{0}$ : mean $\mathrm{CFU}$ door open $=$ mean $\mathrm{CFU}$ door closed

- $\mathrm{H}_{\mathrm{A}}$ : mean $\mathrm{CFU}$ door open $\neq$ mean $\mathrm{CFU}$ door closed

\subsection{Comparisons}

Table 4: Respirators Compared to Surgical Masks, Alpha 0.05

\begin{tabular}{ccccccc} 
Respirator & $\begin{array}{c}\text { Mean } \\
\text { CFU }\end{array}$ & STD & $\begin{array}{c}\text { SM Mean } \\
\text { CFU }\end{array}$ & SM STD & p-Value & Significant \\
\hline Versaflo & 2.54 & 0.94 & 4.12 & 1.53 & 0.001 & YES \\
Air-Mate & 1.95 & 0.83 & 4.12 & 1.53 & 0.000 & YES \\
MAXAIR & 2.14 & 0.83 & 4.12 & 1.53 & 0.000 & YES \\
N-95 & 1.93 & 0.80 & 4.12 & 1.53 & 0.000 & YES \\
Surgical N-95 & 3.24 & 1.34 & 4.12 & 1.53 & 0.000 & YES
\end{tabular}

Table 5: PAPRs Compares to N-95's, Alpha 0.05

N-95

Surgical N-95

$\begin{array}{llllc}\text { Respirator } & \text { p-Value } & \text { Significant } & \text { p-Value } & \text { Significant } \\ \text { Versaflo } & 0.043 & \text { YES } & 0.097 & \text { NO } \\ \text { Air-Mate } & 0.916 & \text { NO } & 0.001 & \text { YES } \\ \text { MAXAIR } & 0.400 & \text { NO } & 0.007 & \text { YES }\end{array}$

Table 6: PAPRs Compared to Each Other, Alpha 0.05

\begin{tabular}{|ccccc|} 
& \multicolumn{2}{c}{ Air-Mate } & \multicolumn{2}{c}{ MAXAIR } \\
\hline & p-Value & Significant & p-Value & Significant \\
\hline Versaflo & 0.045 & YES & 0.180 & NO \\
Air-Mate & & & 0.436 & NO \\
\cline { 2 - 5 } & & & &
\end{tabular}

In Tables 4, 5, and 6 p-values were calculated using a two-sample t-test, assuming equal variance, at an alpha level of 0.05 . The hypothesizes are as follows: 
- $\mathrm{H}_{0}$ : mean $\mathrm{CFU}$ respirator $=$ mean $\mathrm{CFU}$ surgical mask

- $\mathrm{H}_{\mathrm{A}}$ : mean $\mathrm{CFU}$ respirator $\neq$ mean $\mathrm{CFU}$ surgical mask

- $\mathrm{H}_{0}$ : mean $\mathrm{CFU}_{\mathrm{PAPR}}=\mathrm{CFU}_{\mathrm{N}-95}$

- $\mathrm{H}_{\mathrm{A}}$ : mean $\mathrm{CFU}$ PAPR $\neq$ mean $\mathrm{CFU}$ N-95

- $\mathrm{H}_{0}$ : mean CFU PAPR $\mathrm{x}=$ mean CFU PAPR Y

- $\mathrm{H}_{\mathrm{A}}$ : mean CFU PAPR $\mathrm{X} \neq$ mean CFU PAPR Y

To further analyze why two comparisons were deemed different, each plate in the subsequent pairing was compared to determine at what location, if any, the difference occurred. Only significant results from the previous section will be used, due to exhibiting a difference, while the nonsignificant results concluded that there was no difference.

Table 7: Difference in Plate Location for Respirators vs. Surgical Masks

\begin{tabular}{rcccccccccc}
\hline & \multicolumn{2}{c}{ Versaflo } & \multicolumn{2}{c}{ Air-Mate } & \multicolumn{2}{c}{ MAXAIR } & \multicolumn{2}{c}{$\mathrm{N}-95$} & \multicolumn{2}{c}{ S-N-95 } \\
\hline & $\boldsymbol{\alpha}$ & $\mathrm{p}$ & $\boldsymbol{\alpha}$ & $\mathrm{p}$ & $\boldsymbol{\alpha}$ & $\mathrm{p}$ & $\boldsymbol{\alpha}$ & $\mathrm{p}$ & $\boldsymbol{\alpha}$ & $\mathrm{p}$ \\
\hline $\mathbf{1}$ & 0.025 & 0.649 & 0.025 & 0.366 & 0.006 & 0.076 & 0.010 & 0.104 & 0.017 & 0.743 \\
\hline $\mathbf{2}$ & 0.004 & 0.021 & 0.004 & 0.007 & 0.005 & 0.061 & 0.013 & 0.145 & 0.025 & 0.903 \\
\hline $\mathbf{3}$ & 0.006 & 0.157 & 0.006 & 0.017 & 0.013 & 0.134 & 0.006 & 0.051 & 0.003 & 0.149 \\
\hline $\mathbf{4}$ & 0.008 & 0.286 & 0.008 & 0.112 & 0.010 & 0.123 & 0.025 & 0.254 & 0.050 & 1.000 \\
\hline $\mathbf{5}$ & $\mathbf{0 . 0 0 3}$ & $\mathbf{0 . 0 0 1}$ & $\mathbf{0 . 0 0 3}$ & $\mathbf{0 . 0 0 0}$ & $\mathbf{0 . 0 0 3}$ & $\mathbf{0 . 0 0 0}$ & $\mathbf{0 . 0 0 3}$ & $\mathbf{0 . 0 0 1}$ & 0.006 & 0.375 \\
\hline $\mathbf{6}$ & 0.01 & 0.435 & 0.004 & 0.010 & 0.005 & 0.052 & 0.004 & 0.016 & 0.008 & 0.622 \\
\hline $\mathbf{7}$ & 0.004 & 0.064 & 0.005 & 0.012 & 0.004 & 0.021 & 0.005 & 0.031 & 0.006 & 0.370 \\
\hline $\mathbf{8}$ & 0.004 & 0.007 & 0.004 & 0.004 & 0.003 & 0.005 & $\mathbf{0 . 0 0 3}$ & $\mathbf{0 . 0 0 0}$ & 0.003 & 0.098 \\
\hline $\mathbf{9}$ & 0.007 & 0.256 & 0.013 & 0.195 & 0.008 & 0.106 & 0.007 & 0.085 & 0.005 & 0.317 \\
\hline $\mathbf{1 0}$ & $\mathbf{0 . 0 0 3}$ & $\mathbf{0 . 0 0 1}$ & $\mathbf{0 . 0 0 3}$ & $\mathbf{0 . 0 0 1}$ & 0.007 & 0.085 & $\mathbf{0 . 0 0 4}$ & $\mathbf{0 . 0 0 4}$ & 0.004 & 0.197 \\
\hline $\mathbf{1 1}$ & 0.005 & 0.079 & 0.005 & 0.010 & 0.004 & 0.018 & $\mathbf{0 . 0 0 4}$ & $\mathbf{0 . 0 0 2}$ & 0.005 & 0.253 \\
\hline $\mathbf{1 2}$ & 0.006 & 0.141 & 0.007 & 0.018 & 0.004 & 0.018 & 0.006 & 0.037 & 0.010 & 0.660 \\
\hline $\mathbf{1 3}$ & 0.005 & 0.122 & 0.006 & 0.014 & 0.017 & 0.149 & 0.005 & 0.033 & 0.007 & 0.523 \\
\hline $\mathbf{1 4}$ & 0.050 & 0.894 & 0.017 & 0.209 & 0.006 & 0.063 & 0.017 & 0.205 & 0.004 & 0.191 \\
\hline $\mathbf{1 5}$ & 0.013 & 0.493 & 0.010 & 0.148 & 0.025 & 0.586 & 0.008 & 0.096 & 0.004 & 0.202 \\
\hline $\mathbf{1 6}$ & 0.017 & 0.557 & 0.05 & 0.972 & 0.050 & 0.743 & 0.050 & 0.470 & 0.013 & 0.665 \\
\hline & & & & & & & & & \\
\hline
\end{tabular}




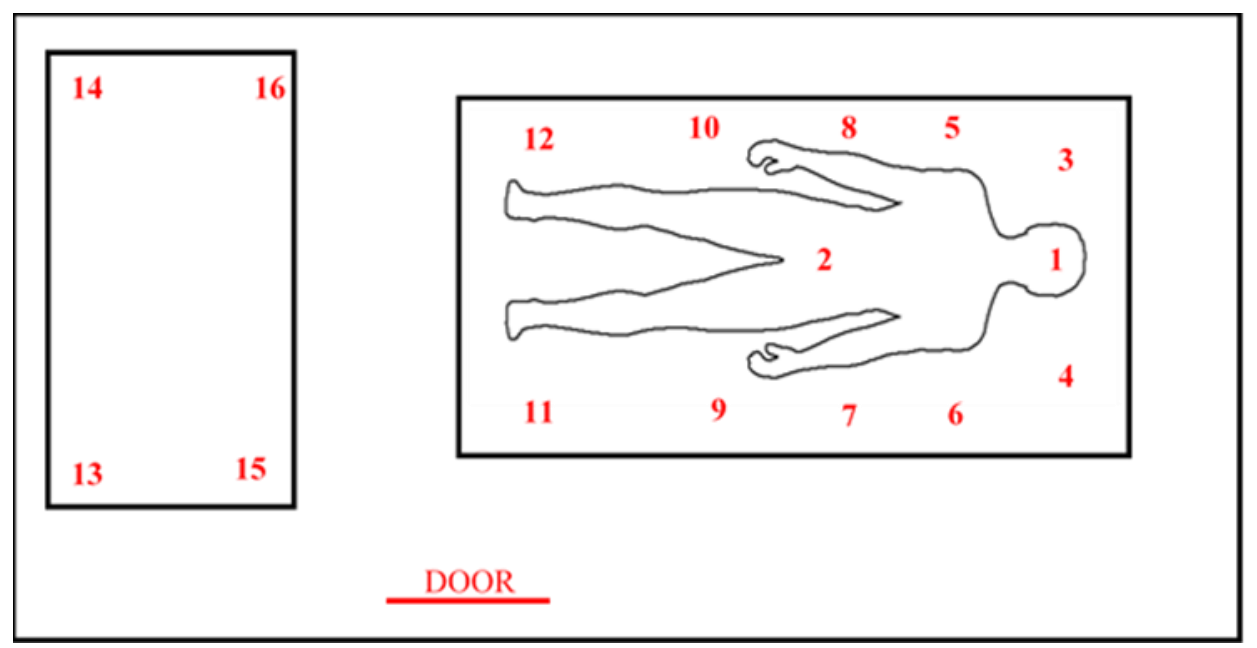

Table 8: Difference in Plate Location for PAPRS vs. Surgical N-95

\begin{tabular}{|c|c|c|c|c|c|c|}
\hline & \multicolumn{2}{|c|}{ Versaflo } & \multicolumn{2}{|c|}{ Air-Mate } & \multicolumn{2}{|c|}{ MAXAIR } \\
\hline & $\alpha$ & $\mathrm{p}$ & $\alpha$ & $\mathrm{p}$ & $\alpha$ & $\mathrm{p}$ \\
\hline 1 & 0.025 & 0.854 & 0.010 & 0.380 & 0.004 & 0.019 \\
\hline 2 & 0.004 & 0.031 & 0.004 & 0.011 & 0.006 & 0.089 \\
\hline 3 & 0.050 & 0.864 & 0.006 & 0.037 & 0.050 & 0.927 \\
\hline 4 & 0.005 & 0.142 & 0.005 & 0.019 & 0.004 & 0.014 \\
\hline 5 & 0.003 & 0.004 & 0.003 & 0.001 & 0.003 & 0.000 \\
\hline 6 & 0.010 & 0.669 & 0.004 & 0.002 & 0.005 & 0.040 \\
\hline 7 & 0.006 & 0.205 & 0.006 & 0.025 & 0.005 & 0.051 \\
\hline 8 & 0.006 & 0.235 & 0.008 & 0.143 & 0.006 & 0.180 \\
\hline 9 & 0.013 & 0.723 & 0.017 & 0.642 & 0.007 & 0.284 \\
\hline 10 & 0.003 & 0.011 & 0.005 & 0.012 & 0.025 & 0.672 \\
\hline 11 & 0.007 & 0.256 & 0.004 & 0.011 & 0.004 & 0.024 \\
\hline 12 & 0.004 & 0.020 & 0.003 & 0.000 & 0.003 & 0.000 \\
\hline 13 & 0.008 & 0.306 & 0.007 & 0.056 & 0.017 & 0.401 \\
\hline 14 & 0.004 & 0.045 & 0.050 & 0.922 & 0.008 & 0.297 \\
\hline 15 & 0.005 & 0.074 & 0.025 & 0.812 & 0.013 & 0.385 \\
\hline 16 & 0.017 & 0.816 & 0.013 & 0.571 & 0.010 & 0.336 \\
\hline
\end{tabular}


Table 7 and 8 above, compares the plate locations of the respirators used to the surgical mask to determine were the difference in CFU was located at, while in Table 9 the comparisons were between PAPRs and the surgical N-95. The p-values were calculated using a two-sample ttest, assuming equal variances, an alpha level of 0.05 . Due to the large number of comparisons, 16 , a correction factor for the alpha value had to be taken into consideration or the possibility of making a Type I error, rejecting $\mathrm{H}_{0}$ when $\mathrm{H}_{0}$ is true, would be greatly increased. This phenome is known as a familywise error or inflation of the alpha value (Abdi, Herve, 2010). To correct for this, a Bonferroni correction factor is usually used, involving dividing the alpha value by the number of comparisons, however the Bonferroni correction can be two conservative and lead to a loss of power and higher probability of a Type II error (Abdi, Herve, 2010). Instead the HolmBonferroni correction factor was utilized. The Holm-Bonferroni correction is done by first calculating the p-values for the given data, then ranking them from smallest to largest with the smallest receiving a rank of 1 (Abdi, Herve, 2010). Next a new alpha value is calculated as follows:

$$
\left(\frac{\alpha}{n-\operatorname{Rank}+1}\right)
$$

Where $\mathrm{n}$ is the number of comparisons, and $\alpha$ is the desired alpha value. This method helps decrease the likely hood of a Type I error, while still being more powerful than the Bonferroni correction factor.

In the Table 7, and 8 above the hypothesizes are stated below

- $\mathrm{H}_{0}$ : mean $\mathrm{CFU}$ respirator $=$ mean $\mathrm{CFU}$ surgical mask

- $\mathrm{H}_{\mathrm{A}}$ : mean $\mathrm{CFU}$ respirator $\neq$ mean $\mathrm{CFU}$ surgical mask

- $\mathrm{H}_{0}$ : mean CFU PAPR = mean CFU surgical $\mathrm{N}-95$

- $\mathrm{H}_{\mathrm{A}}$ : mean CFU PAPR $\neq$ mean CFU surgical N-95

Comparisons highlighted in yellow showed a significant difference in Tables 8 and 9. Note that even though Versaflo vs. N-95, and Versaflo vs. Air-Mate were deemed to be significantly different, when preforming the location calculation there was no significant difference in the mean CFU at any location, thus they were omitted from this section. However, they can be referenced in the Appendix D. 


\subsection{Plates on "Surgical Table" vs. Plates on Back Table}

Table 9: Comparison of Plates on Two Different Tables, Alpha 0.05

\begin{tabular}{rcccc}
\hline Respirator & Surgical Table Mean CFU & Back Table Mean CFU & p-Value & Significant \\
\hline Versaflo & 2.79 & 1.8 & 0.066 & NO \\
\hline Air-Mate & 2.19 & 1.23 & 0.003 & YES \\
\hline MAXAIR & 2.38 & 1.4 & 0.011 & YES \\
\hline N-95 & 2.19 & 1.13 & 0.003 & YES \\
\hline Surgical N-95 & 3.86 & 1.4 & 0.000 & YES \\
\hline Surgical Mask & 4.83 & 2 & 0.000 & YES \\
\hline
\end{tabular}

The above Table 9 compares the 12 plates (1-12) located on the represents surgical table to the 4 plates (13-16) located on the back table. The p-values were calculated using a two-sample t-test, assuming equal variance, at an alpha level of 0.05 . The $\mathrm{H}_{0}$ is stated as no difference in the mean CFU of the surgical table compared to the back table, while the $\mathrm{H}_{\mathrm{A}}$ is stated as a difference between the two tables.

- $\mathrm{H}_{0}$ : mean $\mathrm{CFU}$ surgical table $=$ mean $\mathrm{CFU}$ back table

- $\mathrm{H}_{\mathrm{A}}$ : mean $\mathrm{CFU}$ surgical table $=$ mean $\mathrm{CFU}$ back table

A significant result $(\mathrm{p}<0.05)$ would indicate a difference in the mean CFU between these table, while a nonsignificant result $(\mathrm{p}>0.05)$ would indicate no difference in the mean CFU between these tables. 


\section{Chapter 5: Discussion}

\subsection{Experiments Vs. Controls}

\subsubsection{Negative Controls}

For this experiment the negative controls were a key factor in two ways, one being as a comparison to see if wearing a respirator or surgical mask would generate more bacteria than an empty room, and the second being as a monitor for the background levels per each experiment.

A major worry for this experiment was that bacteria would build up in the small unventilated testing room, due to several trials being completed in one day, anywhere from 1-6. A potential build-up could skew the results in a way at which later trials in the day may present with higher amounts of bacteria than what was truly present. The fear of this potential basis was why the room was thoroughly cleaned between trials and controls were set between experiments. If any build up occurred then one would suspect the controls CFU would increase in number between trials. This was tricky to monitor as it takes approximately 24 hours for bacteria colonies to present on the agar plates. A few preliminary trails were used to test this theory, of which they showed no increase in the control CFU throughout the day. Even though the preliminary findings deemed it safe, the controls for each day were closely monitored. For each day there was no observable increase in the CFU of the controls as the day progressed, showing the cleaning procedure to be adequate. The controls remained consistent with the majority showing 0 or 1 colony forming unit(s) (CFU). Due to the location and lack of ventilation in the room, it was unlikely to be bacteria free even after cleaning, in spite of this the goal was to get the room to be as sterile as possible. The mean control count for each respirator/SM was never higher than $1 \mathrm{CFU}$ (high 0.93, low 0.65), with the overall average being $0.78 \mathrm{CFU}$ for 240 plates. This CFU was deemed acceptable, and shows the cleaning procedure did an adequate job of getting the room as close to sterile as possible.

For each of the respirators and surgical mask tested the mean CFU was shown to be greater than the mean CFU for the empty room, via t-test. One interesting point is both the N-95 and surgical N-95 produced an overall CFU increase. Both of these respirators were fit tested for a good seal prior to use and had no exhalation valve, meaning there should be no route for aerosolized bacteria to escape the filter. This leaves only a few reasons for the increase in bacteria, 
contamination from another source, leakage around the mask, or the possibility that the bacteria were small enough to escape the filter of the mask. That being said, measures were put in place to try and eliminate/limit potential bacteria contamination from other sources like the skin (i.e. gloves, long sleeve lab coat, long pants, cleaning of self and respirators, etc.). Even though the N95s were fit tested there is always the possibility for slight leakage around the mask, especially with mouth movements like talking. The leakage could allow bacteria to go around the filter of the mask and contaminate the field, however due to the proper fit this was likely minimal. The last potential reason is that the bacteria was simply small enough to flow through the filter of the face mask without being captured. N-95's are tested and approved to filter $95 \%$ of particles 0.3 microns and larger from the air, and for a tight-fitting N-95 with no exaltation valve the inverse would likely be true too as the exhalation must past through the same filter. This would likely catch most aerosolized particles produced from a person's mouth and nose. It is important to note that N-95's are only $95 \%$ effective, thus leaving $5 \%$ of particles not being captured. This coupled with the fact that the subject was in a small room lacking ventilation for an hour, preformed talking tasks, allows for a higher chance for bacteria to penetrate the filter and land on a plate. Overall this may have contributed a greater deal to the contamination while, the other reasons mentioned may be present but contributed in a lesser extent.

\subsubsection{Positive Controls}

The positive control was utilized to show if the respirators or surgical mask decreased bacterial contamination in the room compared to not wearing any device and to show the potential hazard associated with not wearing a respirator or surgical mask. Due to the high number of bacteria present in the positive controls it was only completed four times, two with the door open, two with the door closed. It is to be noted that all other cleaning tasks of the room and the subject were performed in the same manner as the other tests, the only difference being the subject was not wearing a respirator or surgical mask. The CFU for the positive control was enormous, with some plate counts being over $100 \mathrm{CFU}$ and the overall mean being $25.89 \mathrm{CFU}$. Given this information, every respirator and surgical mask showed significantly less CFU, than the positive control (highest being the SM at 4.12). The main difference is that there is no barrier to catch droplets from the subject's mouth and nose. All other devices tested had some form of material in front of the user's mouth/nose that could prevent droplets entering the field. Without any protective 
barrier these droplets can be expelled directly into the testing room. The drastic increase also shows what a danger an unprotected worker is to a sterile field, and that a simple surgical mask may greatly reduce the spread of bacteria.

\subsection{Effect of Ambient Air Exchange}

As stated previously, the room the trial was performed in had no ventilation. To combat this, the door was used to create two environments, one being no air exchange (door closed), and the second being ambient air exchange (door completely opened). This is a simplification of ventilation, however it still can be used to show how much, if any, ventilation can affect the contamination of a sterile room when using various respirators and a surgical mask. From a simple design the potential to look more in-depth at ventilation can be researched in future studies.

Only the Air-Mate showed a significant difference in mean CFU at the alpha 0.05 threshold while the Versaflo, surgical N-95 and surgical mask would be significant at the alpha 0.10 level. The N-95 and MAXAIR showed no difference in means when comparing the door open to the door closed. That being said it is curious that the surgical-N-95 did not show similar results as both are certified by NIOSH, and were successfully fit tested for a good seal on the subject. One possible reason is linked to the overall CFU generation from these respirators, N-95 being a mean of 1.93 CFU, and surgical N-95 being a mean of 3.24 CFU. Perhaps, the N-95 was more efficient in capturing bacteria than the surgical N-95 thus suggesting a lower concentration of bacteria in the air. The concentration could have been low enough so that the ambient air exchange had little effect on removing bacteria, as it was just not enough. On the other hand, the surgical N-95 resulted in a higher concentration of bacteria in the air allowing the air exchange to show a noticeable effect on the CFU count. The same reasoning can be applied to the surgical mask as well.

For the PAPRs one must consider what a PAPR does different from a N-95. Instead of the user breathing though a filter, a PAPR intakes air through a filter and blows the cleaned air into a helmet worn by the user, then into the environment. The added airflow the PAPR creates could help facilitate air exchange, especially in a small environment such as the testing room. The added airflow would help air exchange happen quicker, resulting in more bacteria removal compared to a slower exchange rate associated with the N-95, surgical N-95, and SM. The inverse could also be said, as in a closed room the air has no were to go and the increase in air movement could cause 
the bacteria in the air to have a higher chance to interact with an agar plate resulting in a larger CFU.

When the plate CFU per location was analyzed between door open and door closed for each respirator or surgical mask, no significantly different plate location was found. This concludes that the effect of the air exchange had a general overall effect on the CFU not just an effect at one location.

\subsection{Comparison of Respirators and a Surgical Mask}

\subsubsection{Respirators to Surgical Masks}

A surgical mask is designed to be worn by anyone and acts as a barrier to prevent bacteria from spreading via the wear to another person or from another person to the wearer. As shown when comparing the positive control to the surgical mask, it does just that, offering substantially more protection than wearing nothing at all. However, in this experiment, it was shown that the surgical mask produced more CFU than all the other respirators evaluated. These results are likely due to the surgical mask loosely fitting around the subject's face, thus air could escape around the sides of the mask and contaminate the field. In contrast the N-95's were tight fitting, avoiding this issue and resulting in a lower CFU. The PAPRs were loose fitting, with two models, Versaflo and MAXAIR, having double shroud hoods. The inner of which was tucked into the subject's lab coat, and the outer was rested over the shoulders. These shrouds likely helped direct the air down away from the table, and allowed a higher chance for particles containing bacteria to contact some material and get stuck, i.e. clothes, hood, or shroud. The helmet and face shield also served as a direct barrier to stop higher accelerated particles from escaping the system, like a sneeze or cough may produce. The third PAPR is a bit tricky to discuss as the hood system loosely covered the face of the subject. The hood itself had little holes cut into to that acted as exhalation values. One would think that the design would result in a mean CFU to be about the same as the surgical mask, as both had paths aerosolized bacteria could circumnavigate the barrier, yet this was not the case. It is unclear why this result was seen, but it may have to due with the PAPR creating a downward air flow from then outlet in the hood. This air flow could push potential aerosolized bacteria down away from the table, while the surgical mask may result in the bacteria lingering in the air longer, allowing a higher chance to contact a plate. 
The next step was to determine if the significantly different results obtained was due to any specific plate location or due to an overall effect. Though statically analysis is was determined that plate 5 showed a significant difference for 4 of 5 respirators, Versaflo, Air-Mate, MAXAIR, and N-95, compared to the surgical mask. Additionally, 3 of 5 respirators, Versaflo, Air-Mate, N-95, showed a significant difference in plate 10, and the N-95 showed a difference in plates 8 and 11. Plates 5, 8, and 10 are all in row opposite the door, so being further away from the door may have lead to less air exchange, explaining why this difference isn't seen in the plates counter parts on the other side. Another explanation is due to proximity to the subject, as during the trials the subject was to stand between plates 5 and 8 when on the non-door side of the table. This would be reasonable as the difference in plate 5 was seen across several respirators. The only problem is that if one would suspect plate 8 to experience a similar difference compared to plate 5 since the subject stood between them. Instead the plates on either side of 8,5 and 10 were shown to be different.

The surgical N-95 was the only respirator of the ones tested that showed no single plate difference compared to the surgical mask. This is a bit surprising as the other N-95 showed the largest number of plates being different at 4. Even though both are N-95s and were successfully fit tested it appears the surgical N-95 is closer to a surgical mask compare to a N-95 when looking at the potential for bacterial contamination.

\subsubsection{PAPRs to N-95's}

All three PAPRs produced significantly less bacteria contamination than the surgical N95. This is surprising as one would suspect a tight-fitting respirator approved for use in a surgical room to contaminate a field less than an unapproved PAPR. As stated previously in other sections there is three possible reasons for the large amount of CFU found during the surgical N-95 experiment, 1) Bacteria on small enough to pass the filter 2) leakage around the edges of the mask 3) contamination from other sources i.e. cloths, skin, contaminated agar plates. For more detail reference the Controls section of the discussion.

Two of the three PAPRs, Air-Mate and MAXAIR, showed no difference in CFU compared to the N-95 respirator. This show that both these models may be just as effective at maintain a sterile environment as a N-95. While the third, Versaflo, showed a significantly higher CFU than the N-95. The Versaflo may have had a higher CFU due to the way the hood was designed. The 
hood was a double shroud with the inner shroud being tucked in to the subject lab coat and the other shroud covering the shoulders much like the MAXAIR. However, the MAXAIR shrouds were thinner and more flexible allowing them to stay close to the body even when leading over, while the Versaflo shrouds was thicker and ridged often moving from the body when leaning over the manakin. This difference in performance is likely why the Versaflo was showed significantly higher CFU than the N-95 while the MAXAIR was concluded at no difference compared to the N95.

\subsubsection{PAPRs to Each Other}

The MAXAIR and Versaflo had similar design helmets/hoods, both being double shrouded as mentioned previously. The similar design is likely why they had no difference in mean CFU when compared. On the other hand, the Air-Mate had a much smaller face piece worn by the user, with small holes present to act as exhalation values. The MAXAIR and Air-Mate showed no difference between the CFU generation while the Versaflo and Air-Mate was deemed significantly different. As mentioned before the reason the Air-Mate was so low is not understood as one would suspect the hood design to be less effective at preventing bacterial contamination.

\subsection{Plates on "Surgical Table" vs. Plates on Back Table}

When comparing the plates of theses two locations the goal was to determine if there was a difference in CFU generation within proximity to the patient (manakin). From the t-tests it was shown that five out of six of the respirators/SM tested showed a difference in the CFU generation from the surgical table to the back table. It appears that the majority of respirators tested had a more substantial effect on the plates close to were the subject stood, while having a lesser effect on further away plates. This makes sense as one would expect an increase in contamination close to the subject. The only respirator that defies this trend is the Versaflo, showing no difference between the surgical table and the back table. A likely explanation for this is that the Versaflo created an overall increase in contamination by blowing contaminated air all around the room more so than the other models tested. 


\subsection{Limitations}

To further strengthen the relationships on the data similar tests should be preformed in an actual operating room (OR). Simple air exchange has been shown to affect the results in this study, so it would be reasonable to believe that a proper ventilation system may significantly impact the results. In addition, with a OR it should be possible to completely sterilize the field compared to the environment tested for this study. A true sterile environment will help further isolate the various respirators or surgical mask from background levels. As with most studies more samples could be taken, to help limit variability between trials. Additional subjects could also be used, as different facial types, or heights may impact the results. It was noted that during the reading procedure the subject took progressively less time to read the rainbow passage, so a possible solution might be to read for the two full minutes instead of reading once through.

\subsection{Conclusion}

Overall it was shown that wearing any of the respirators or surgical mask substantially decrease the amount of bacterial contamination compared to an unprotected subject. It was also noted that all respirators and the surgical mask that were tested produced an overall contamination compared to that of an empty room. Ambient air exchange was also deemed a factor in CFU generation as three respirators and the surgical mask had a lower CFU for the open door compared to the closed one at an alpha level of 0.10 . When compering the respirators to the surgical mask it was shown that all respirators tested produced less CFU than the surgical mask and in conjunction all PAPRs produced less CFU than the surgical N-95. However, when comparing the PAPRs to the N-95 the Air-Mate and MAXAIR showed no difference in CFU while the Versaflo had a significantly higher CFU. From further break down it was determined that the majority of the noted differences were due to plates 5 and 10. From this data it appears that the Air-Mate and MAXAIR may be suitable for use in a sterile OR environment, while the Versaflo may not be suitable. 


\section{References}

1. 3M. Cleaning Reusable Respirators and Powered Air Purifying Respirator Assemblies. 3 July 2017.

2. 3M. “Assigned Protection Factors.” 3M Regulations Update, Nov. 2006.

3. 3M. Respiratory Protection for Airborne Exposures to Biohazards. 2 Jan. 2018.

4. Abdi, Herve. "Holm's Sequential Bonferroni Procedure.” In Neil Salkind (Ed.), Encyclopedia of Research Design. Thousand Oaks, CA: 2010.

5. Bałazy, Anna, et al. "Do N95 Respirators Provide 95\% Protection Level against Airborne Viruses, and How Adequate Are Surgical Masks?" American Journal of Infection Control, vol. 34, no. 2, 2006, pp. 51-57., doi:10.1016/j.ajic.2005.08.018.

6. "Bonferroni Correction." Statistics Solutions, 31 Mar. 2015, www.statisticssolutions.com/bonferroni-correction/.

7. Boyce, John M. "Alcohols as Surface Disinfectants in Healthcare Settings." Infection Control \& Hospital Epidemiology, vol. 39, no. 03, 2018, pp. 323-328., doi:10.1017/ice.2017.301.

8. "CDC - NIOSH - NPPTL Respirator Trusted-Source, NIOSH-Approved Respirators, How Can They Be Identified?" Centers for Disease Control and Prevention, 29 Jan. 2018.

9. Center for Devices and Radiological Health. "Personal Protective Equipment for Infection Control." U S Food and Drug Administration Home Page, Center for Drug Evaluation and Research, 16 May 2018.

10. Coffey, C., et al. "221. The Efficacy of Four Fit-Test Methods with N95 FilteringFacepiece Respirators.” AIHce 2000, 2002, doi:10.3320/1.2763556.

11. Edmiston, Charles E., et al. "Molecular Epidemiology of Microbial Contamination in the Operating Room Environment: Is There a Risk for Infection?” Surgery, vol. 138, no. 4, Oct. 2005, pp. 573-582., doi:10.1016/j.surg.2005.06.045.

12. "Familywise Error Rate (Alpha Inflation): Definition." Statistics How To, 24 Oct. 2017, www.statisticshowto.datasciencecentral.com/familywise-error-rate/.

13. Fairbanks, G. (1960). Voice and articulation drillbook, 2nd edn. New York: Harper \& Row. pp124-139. 
14. Grinshpun, Sergey. "Simulation Study: Does the Air Exhaled from a PAPR Wearer Contaminate the Sterile Field in an Operating Room?" Department of Environmental Health, University of Cincinnati.

15. Hospital Respiratory Protection Program Toolkit. OSHA, May 2015.

16. "Infection Control." Centers for Disease Control and Prevention, Centers for Disease Control and Prevention, 18 Sept. 2016.

17. Kim, Yoojin, and Molly Hale. "Pilot Study to Examine the Use of a Powered Air Purifying Respirator (PAPR) in the Operating Room." American Journal of Infection Control, vol. 45, no. 6, 2017, doi:10.1016/j.ajic.2017.04.124.

18. Lee, Shu-An, et al. "Respiratory Performance Offered by N95 Respirators and Surgical Masks: Human Subject Evaluation with $\mathrm{NaCl}$ Aerosol Representing Bacterial and Viral Particle Size Range.” The Annals of Occupational Hygiene, vol. 52, no. 3, 7 Mar. 2008, pp. 177-185., doi:10.1093/annhyg/men005.

19. Loeb, Mark, et al. "Surgical Mask vs N95 Respirator for Preventing Influenza Among Health Care Workers." Jama, vol. 302, no. 17, 2009, p. 1865. , doi:10.1001/jama.2009.1466.

20. Liverman, Cathary T., et al. The Use and Effectiveness of Powered Air Purifying Respirators in Health Care: Workshop Summary. The National Academies Press, 2015.

21. Moldex ${ }^{\circledR}$. "A COMPARISON OF SURGICAL MASKS, SURGICAL N95 RESPIRATORS \& INDUSTRIAL P2 RESPIRATORS.” Moldex ${ }^{\circledR}$ Australia - Hearing and Respiratory Protection, Aug. 2012, www.moldex.com/au/non-product/techbriefs/respiratory/comp-respirators-and-surgical.php.

22. OSHA. Assigned Protection Factors for the Revised Respiratory Protection Standard. 2009, www.osha.gov.

23. Radonovich, Lew. Elastomeric and Powered-Air Purifying Respirators in U.S. Healthcare. 5 Sept. 2017.

24. "Respiratory Protective Devices Used in Healthcare." Federal Register, 14 Mar. 2014,

25. Roberts, Vanessa. To PAPR or Not to PAPR? 2014.

26. Smith, Jeffrey D., et al. "Effectiveness of N95 Respirators versus Surgical Masks in Protecting Health Care Workers from Acute Respiratory Infection: a Systematic Review and Meta-Analysis." Canadian Medical Association Journal, vol. 188, no. 8, 2016, pp. 567-574., doi:10.1503/cmaj.150835. 
27. Wizner, Kerri, et al. "Prevalence of Respiratory Protective Devices in U.S. Health Care Facilities.” Workplace Health \& Safety, vol. 64, no. 8, 2016, pp. 359-368., doi:10.1177/2165079916657108.

28. Zhiqing, Liu, et al. "Surgical Masks as Source of Bacterial Contamination during Operative Procedures." Journal of Orthopaedic Translation, vol. 14, 14 July 2018, pp. 57-62., doi:10.1016/j.jot.2018.06.002. 


\section{Appendix A: Rainbow Passage}

When the sunlight strikes raindrops in the air, they act as a prism and form a rainbow. The rainbow is a division of white light into many beautiful colors. These take the shape of a long round arch, with its path high above, and its two ends apparently beyond the horizon. There is, according to legend, a boiling pot of gold at one end. People look, but no one ever finds it. When a man looks for something beyond his reach, his friends say he is looking for the pot of gold at the end of the rainbow. Throughout the centuries people have explained the rainbow in various ways. Some have accepted it as a miracle without physical explanation. To the Hebrews it was a token that there would be no more universal floods. The Greeks used to imagine that it was a sign from the gods to foretell war or heavy rain. The Norsemen considered the rainbow as a bridge over which the gods passed from earth to their home in the sky. Others have tried to explain the phenomenon physically. Aristotle thought that the rainbow was caused by reflection of the sun's rays by the rain. Since then physicists have found that it is not reflection, but refraction by the raindrops which causes the rainbows. Many complicated ideas about the rainbow have been formed. The difference in the rainbow depends considerably upon the size of the drops, and the width of the colored band increases as the size of the drops increases. The actual primary rainbow observed is said to be the effect of super-imposition of a number of bows. If the red of the second bow falls upon the green of the first, the result is to give a bow with an abnormally wide yellow band, since red and green light when mixed form yellow. This is a very common type of bow, one showing mainly red and yellow, with little or no green or blue. 


\section{Appendix B: Fit Testing Results}

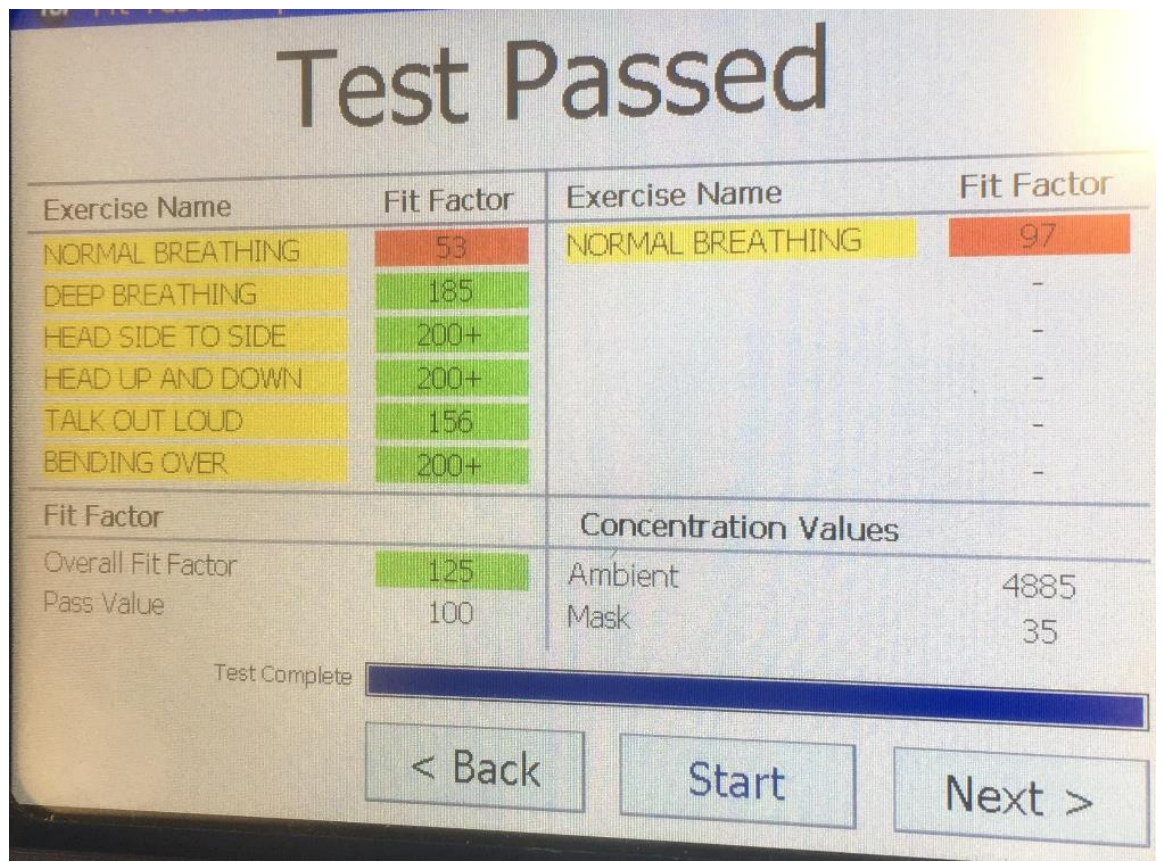

Fit Testing Results for N-95

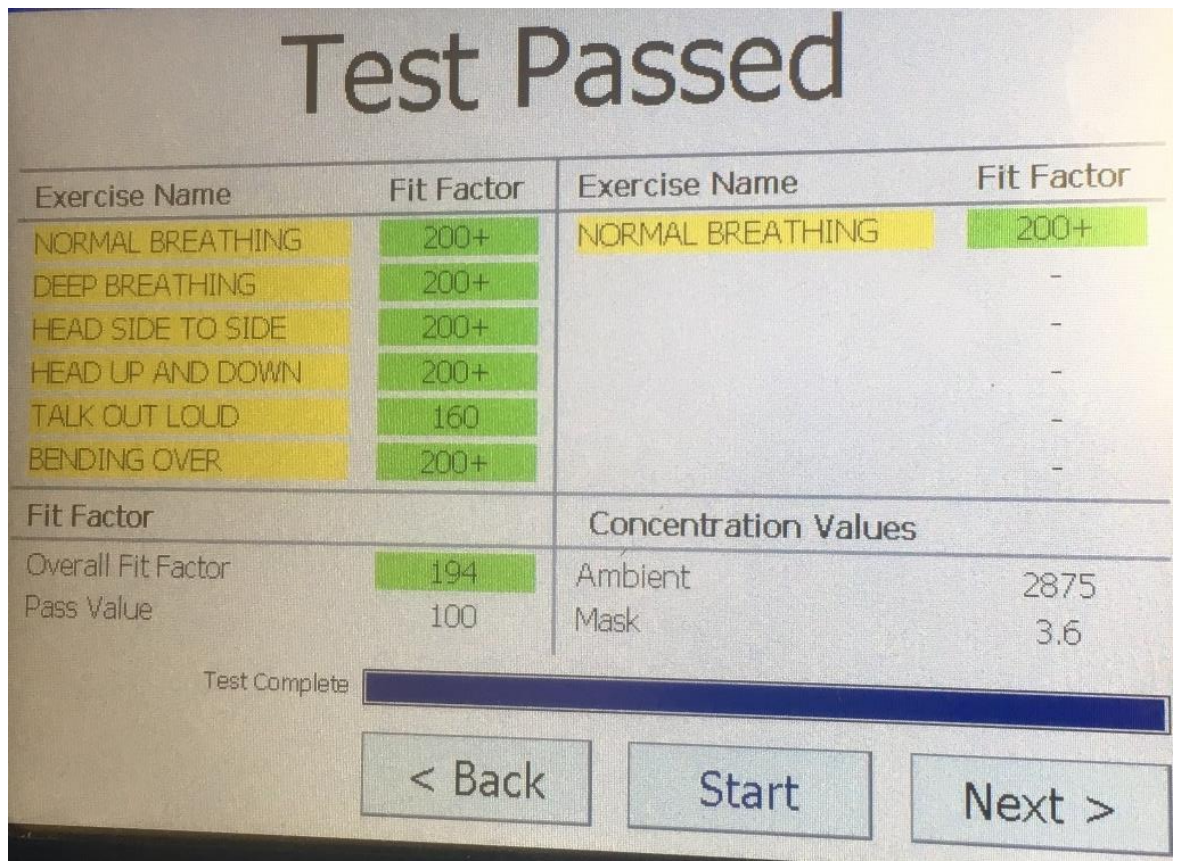

Fit Testing Results for Surgical N-95 


\section{Appendix C: Raw Data}

\begin{tabular}{|c|c|c|c|c|c|c|c|c|c|c|c|c|c|c|c|c|c|c|c|c|c|c|c|c|}
\hline & KEY & & DO & & & & & & & & & & & & & & & & & & & & & \\
\hline & VersaFlo & & Op & & & & & & & & & & & & & & & & & & & & & \\
\hline & VersaFlo & & Clo & sed & & & & & & & & & & & & & & & & & & & & \\
\hline & Air Mate & & Op & & & & & & & & & & & & & & & & & & & & & \\
\hline & Air Mate & & Clo & sed & & & & & & & & & & & & & & & & & & & & \\
\hline & Maxair & & Op & & & & & & & & & & & & & & & & & & & & & \\
\hline & Maxair & & Clo & sed & & & & & & & & & & & & & & & & & & & & \\
\hline & N-95 & & Op & & & & & & & & & & & & & & & & & & & & & \\
\hline 81 & N-95 & & Clo & sed & & & & & & & & & & & & & & & & & & & & \\
\hline $9 \mathrm{P}$ & Postive C & ontrol & I Op & & & & & & & & & & & & & & & & & & & & & \\
\hline $10 \mathrm{P}$ & Postive C & ontrol & $\mathrm{I} \mathrm{Clo}$ & sed & & & & & & & & & & & & & & & & & & & & \\
\hline $11 \mathrm{~s}$ & Surgical N & lask & Op & & & & & & & & & & & & & & & & & & & & & \\
\hline $12 \mathrm{~s}$ & Surgical $\mathrm{N}$ & lask & Clo & sed & & & & & & & & & & & & & & & & & & & & \\
\hline $13 s$ & Surgical N & $1-95$ & Op & & & & & & & & & & & & & & & & & & & & & \\
\hline $14 \mathrm{~s}$ & Surgical N & $1-95$ & Clo & sed & & & & & & & & & & & & & & & & & & & & \\
\hline Set up & $\mathrm{C} 1$ & C2 & $\mathrm{C3}$ & $\mathrm{C} 4$ & $\mathrm{~T} 1$ & $\mathrm{~T} 2$ & T3 & T4 & $\mathrm{T} 5$ & T6 & $\mathrm{T} 7$ & T8 & T9 & $\mathrm{T} 10$ & $\mathrm{~T} 11$ & $\mathrm{~T} 12$ & $\mathrm{~T} 13$ & T14 & $\mathrm{T} 15$ & T16 Total & Average STD & C-Total C- & -Average & C-STD \\
\hline 1,1 & 2 & 1 & 2 & 2 & 4 & 1 & 0 & 0 & 3 & 4 & 3 & 4 & 2 & 3 & 1 & 3 & 5 & 4 & 4 & $4 \quad 45$ & $2.81^{\prime} 1.56^{\prime}$ & 7 & $1.75^{\prime}$ & 0.50 \\
\hline 1,2 & 0 & 0 & 1 & 1 & 3 & 1 & 0 & 2 & 1 & 3 & 3 & 3 & 2 & 0 & 0 & 1 & 0 & 1 & 1 & 1 & $1.38^{\prime} 1.15^{\prime}$ & 2 & $0.50^{\circ}$ & 0.58 \\
\hline 1,3 & 0 & 0 & 2 & 1 & 3 & 4 & 1 & 3 & 0 & 8 & 4 & 1 & 0 & 0 & 1 & 1 & 1 & 1 & 3 & $2^{7}$ & $2.06^{\prime} 2.08^{\prime}$ & 3 & $0.75^{\prime}$ & 0.96 \\
\hline 1,4 & 1 & 1 & 0 & 0 & 3 & 3 & 5 & 3 & 4 & 3 & 2 & 4 & 2 & 3 & 4 & 2 & 1 & 5 & 1 & $0^{7}$ & $2.81^{\top} 1.42^{\nabla}$ & 2 & $0.50^{7}$ & 0.58 \\
\hline 1,5 & 0 & 1 & 0 & 1 & 4 & 1 & 7 & 2 & 1 & 4 & 3 & 3 & 0 & 0 & 0 & 2 & 0 & 1 & 3 & 32 & $2.00^{\prime} 1.93^{\mathrm{V}}$ & 2 & $0.50^{\prime \prime}$ & 0.58 \\
\hline Average 1 & 0.6 & 0.6 & 1 & 1 & 3.4 & 2 & 2.6 & 2 & 1.8 & 4.4 & 3 & 3 & 1.2 & 1.2 & 1.2 & 1.8 & 1.4 & 2.4 & 2.4 & $1.6^{\prime}$ & $2.210 .90^{\prime}$ & $16^{\prime}$ & 0.80 & 0.23 \\
\hline 2,1 & 0 & 1 & 0 & 1 & 5 & 4 & 6 & 6 & 6 & 6 & 7 & 5 & 10 & 2 & 6 & 6 & 0 & 3 & 7 & 80 & $5.00^{\prime \prime} \quad 2.5^{\prime \prime}$ & 2 & $0.50^{\prime}$ & 0.58 \\
\hline 2,2 & 0 & 2 & 2 & 0 & 4 & 3 & 3 & 3 & 4 & 4 & 5 & 5 & 3 & 1 & 2 & 1 & 2 & 2 & 1 & 43 & $2.69^{\prime} \quad 1.5^{\prime}$ & 4 & $1.00^{\prime}$ & 1.15 \\
\hline 2,3 & 0 & 0 & 1 & 0 & 9 & 0 & 4 & 9 & 4 & 12 & 2 & 4 & 3 & 2 & 5 & 4 & 3 & 2 & 2 & 1 & $4.13^{\prime} \quad 3.2^{\prime}$ & 1 & $0.25^{\prime}$ & 0.50 \\
\hline 2,4 & 0 & 0 & 1 & 0 & 1 & 1 & 1 & 0 & 1 & 2 & 1 & 2 & 0 & 2 & 1 & 0 & 1 & 4 & 3 & $0^{7}$ & $1.25^{\prime \prime} \quad 1.1^{\prime \prime}$ & 1 & $0.25^{\prime \prime}$ & 0.50 \\
\hline 2,5 & 1 & 0 & 3 & 0 & 4 & 4 & 3 & 0 & 0 & 1 & 1 & 1 & 1 & 2 & 2 & 1 & 0 & 1 & 0 & 21 & $1.31^{\prime \prime} 1.4^{\prime \prime}$ & 4 & $1.00^{\prime}$ & 1.41 \\
\hline Average 2 & 0.2 & 0.6 & 1.4 & 0.2 & 4.6 & 2.4 & 3.4 & 3.6 & 3 & 5 & 3.2 & 3.4 & 3.4 & 1.8 & 3.2 & 2.4 & 1.2 & 2.4 & 2.6 & 0.4 & $2.88 \quad 1.15$ & 12 & 0.6 & 0.57 \\
\hline Total $1+2$ & 0.4 & 0.6 & 1.2 & 0.6 & 4 & 2.2 & 3 & 2.8 & 2.4 & 4.7 & 3.1 & 3.2 & 2.3 & 1.5 & 2.2 & 2.1 & 1.3 & 2.4 & 2.5 & 407 & $\begin{array}{ll}2.54 & 0.94\end{array}$ & 28 & 0.70 & 0.35 \\
\hline 3,1 & 1 & 2 & 1 & 1 & 3 & 1 & 0 & 1 & 2 & 2 & 5 & 3 & 2 & 2 & 3 & 1 & 0 & 1 & 1 & 29 & $1.81^{\prime} 1.28^{\prime \prime}$ & 5 & $1.25^{\prime}$ & 0.50 \\
\hline 3,2 & 2 & 0 & 1 & 0 & 4 & 1 & 1 & 3 & 1 & 4 & 1 & 4 & 0 & 2 & 0 & 2 & 1 & 0 & 0 & 24 & $1.50^{\prime} 1.51^{\prime \prime}$ & 3 & $0.75^{\prime \prime}$ & 0.96 \\
\hline 3,3 & 1 & 0 & 0 & 0 & 2 & 0 & 2 & 1 & 2 & 1 & 1 & 0 & 4 & 1 & 1 & 1 & 0 & 0 & 2 & 20 & $1.25^{\mathrm{V}} 1.06^{\mathrm{V}}$ & 1 & $0.25^{\prime \prime}$ & 0.50 \\
\hline 3,4 & 0 & 0 & 0 & 1 & 1 & 2 & 1 & 1 & 3 & 2 & 2 & 1 & 2 & 1 & 1 & 0 & 0 & 1 & 1 & 19 & $1.19^{\prime} 0.83^{\prime}$ & 1 & $0.25^{\prime \prime}$ & 0.50 \\
\hline 3,5 & 0 & 0 & 0 & 2 & 4 & 2 & 2 & 0 & 3 & 0 & 4 & 6 & 1 & 2 & 3 & 1 & 1 & 0 & 2 & 33 & $2.06^{\prime \prime} 1.65^{\prime \prime}$ & 2 & $0.50^{\prime \prime}$ & 1.00 \\
\hline Average 3 & 0.8 & 0.4 & 0.4 & 0.8 & 2.8 & 1.2 & 1.2 & 1.2 & 2.2 & 1.8 & 2.6 & 2.8 & 1.8 & 1.6 & 1.6 & 1 & 0.4 & 0.4 & 1.2 & $1.2^{\prime}$ & $\begin{array}{ll}1.56 & 0.75^{\prime}\end{array}$ & $12^{\prime}$ & 0.6 & 0.23 \\
\hline 4,1 & 2 & 2 & 2 & 1 & 2 & 2 & 0 & 1 & 2 & 1 & 0 & 2 & 3 & 1 & 2 & 2 & 2 & 0 & 0 & 22 & $1.38^{\prime \prime} 0.96^{\prime \prime}$ & 7 & $1.75^{\prime}$ & 0.50 \\
\hline 4,2 & 1 & 1 & 0 & 0 & 2 & 4 & 1 & 6 & 3 & 3 & 1 & 2 & 4 & 1 & 3 & 4 & 0 & 2 & 0 & $2^{7}$ & $2.38^{\prime \prime} 1.63^{\prime \prime}$ & 2 & $0.50^{\prime \prime}$ & 0.58 \\
\hline 4,3 & 0 & 3 & 0 & 3 & 3 & 2 & 3 & 3 & 1 & 3 & 3 & 4 & 2 & 3 & 1 & 1 & 1 & 5 & 2 & $1^{\prime}$ & $2.38^{\nabla} 1.20^{\nabla}$ & 6 & $1.50^{\prime}$ & 1.73 \\
\hline 4,4 & 0 & 2 & 1 & 2 & 6 & 3 & 4 & 1 & 3 & 4 & 2 & 4 & 3 & 2 & 1 & 1 & 3 & 2 & 2 & 2 & $2.69^{\prime} 1.35^{\prime}$ & 5 & $1.25^{\prime \prime}$ & 0.96 \\
\hline 4,5 & 2 & 0 & 0 & 2 & 7 & 3 & 4 & 5 & 3 & 3 & 2 & 3 & 2 & 2 & 2 & 3 & 2 & 2 & 2 & $1^{\prime}$ & $2.88^{\prime \prime} 1.45^{\prime \prime}$ & 4 & $1.00^{\prime}$ & 1.15 \\
\hline Average 4 & 1 & 1.6 & 0.6 & 1.6 & 4 & 2.8 & 2.4 & 3.2 & 2.4 & 2.8 & 1.6 & 3 & 2.8 & 1.8 & 1.8 & 2.2 & 1.6 & 2.2 & 1.2 & 1.6 & $2.34 \quad 0.74$ & 24 & 1.2 & 0.49 \\
\hline $\begin{array}{l}\text { Total } 3+4 \\
5,1\end{array}$ & $\begin{array}{r}0.9 \\
1\end{array}$ & $\frac{1}{2}$ & $\begin{array}{r}0.5 \\
0\end{array}$ & $\begin{array}{r}1.2 \\
1\end{array}$ & $\begin{array}{r}3.4 \\
3\end{array}$ & ${ }_{1}^{2}$ & $\begin{array}{r}1.8 \\
2\end{array}$ & $\begin{array}{r}2.2 \\
1\end{array}$ & $\begin{array}{r}2.3 \\
1\end{array}$ & $\begin{array}{r}2.3 \\
1\end{array}$ & $\begin{array}{r}2.1 \\
1\end{array}$ & $\begin{array}{r}2.9 \\
5\end{array}$ & $\begin{array}{r}2.3 \\
1\end{array}$ & $\begin{array}{r}1.7 \\
4\end{array}$ & $\begin{array}{r}1.7 \\
2\end{array}$ & $\begin{array}{r}1.6 \\
1\end{array}$ & $\begin{array}{l}1 \\
4\end{array}$ & $\begin{array}{r}1.3 \\
0\end{array}$ & $\begin{array}{r}1.2 \\
1\end{array}$ & 1.4 & $\begin{array}{ll}1.95 & 0.63 \\
2.00 & 1.51\end{array}$ & $\begin{array}{r}36 \\
4\end{array}$ & $\begin{array}{r}0.9 \\
1.00\end{array}$ & $\begin{array}{l}0.29 \\
0.82\end{array}$ \\
\hline 5,2 & 1 & 0 & 0 & 1 & 1 & 3 & 1 & 2 & 1 & 2 & 1 & 3 & 0 & 3 & 2 & 1 & 0 & 2 & 0 & 23 & $1.44^{\prime} 1.03^{\prime}$ & 2 & $0.50^{\prime}$ & 0.58 \\
\hline 5,3 & 1 & 0 & 1 & 0 & 2 & 3 & 3 & 4 & 2 & 3 & 2 & 2 & 3 & 4 & 2 & 2 & 2 & 0 & 2 & 37 & $2.31^{\prime} 1.01^{\prime \prime}$ & 2 & $0.50^{\prime}$ & 0.58 \\
\hline 5,4 & 0 & 0 & 1 & 0 & 1 & 4 & 4 & 1 & 1 & 5 & 3 & 4 & 0 & 2 & 3 & 3 & 0 & 3 & 3 & 38 & $2.38^{\prime \prime} 1.54^{\prime \prime}$ & 1 & $0.25^{\prime \prime}$ & 0.50 \\
\hline 5,5 & 0 & 0 & 1 & 1 & 1 & 2 & 3 & 3 & 1 & 0 & 2 & 3 & 2 & 1 & 2 & 2 & 1 & 0 & 1 & 24 & $1.50^{\prime} 1.03^{\prime}$ & 2 & $0.50^{\prime \prime}$ & 0.58 \\
\hline Average 5 & 0.6 & 0.4 & 0.6 & 0.6 & 1.6 & 2.6 & 2.6 & 2.2 & 1.2 & 2.2 & 1.8 & 3.4 & 1.2 & 2.8 & 2.2 & 1.8 & 1.4 & 1 & 1.4 & $1.4^{\prime}$ & $\begin{array}{ll}1.93 & 0.68^{\prime}\end{array}$ & $11^{\prime}$ & 0.55 & 0.10 \\
\hline 6,1 & 1 & 0 & 2 & 0 & 2 & 2 & 2 & 3 & 0 & 1 & 2 & 0 & 1 & 1 & 1 & 0 & 1 & 0 & 1 & 19 & $1.19^{\prime} 0.91^{\prime \prime}$ & 3 & $0.75^{\prime}$ & 0.96 \\
\hline 6,2 & 0 & 1 & 2 & 0 & 4 & 3 & 6 & 3 & 2 & 8 & 4 & 4 & 5 & 5 & 3 & 1 & 2 & 1 & 2 & 55 & $3.44^{\prime \prime} 1.90^{\prime \prime}$ & 3 & $0.75^{\prime}$ & 0.96 \\
\hline 6,3 & 1 & 1 & 2 & 3 & 2 & 4 & 4 & 0 & 1 & 3 & 3 & 4 & 4 & 4 & 2 & 2 & 3 & 1 & 2 & 41 & $2.56^{\prime \prime} 1.26^{\prime \prime}$ & 7 & $1.75^{\prime}$ & 0.96 \\
\hline 6,4 & 0 & 0 & 0 & 0 & 4 & 3 & 3 & 4 & 2 & 4 & 1 & 1 & 0 & 3 & 2 & 1 & 1 & 0 & 4 & 35 & $2.19^{\prime} 1.42^{\prime}$ & 0 & $0.00^{\prime \prime}$ & 0.00 \\
\hline 6,5 & 1 & 1 & 0 & 0 & 3 & 3 & 3 & 2 & 2 & 4 & 6 & 4 & 2 & 2 & 0 & 3 & 1 & 1 & 1 & 38 & $2.38^{\prime} 1.50^{\prime \prime}$ & 2 & $0.50^{\prime}$ & 0.58 \\
\hline Average 6 & 0.6 & 0.6 & 1.2 & 0.6 & 3 & 3 & 3.6 & 2.4 & 1.4 & 4 & 3.2 & 2.6 & 2.4 & 3 & 1.6 & 1.4 & 1.6 & 0.6 & 2 & 1.8 & $\begin{array}{ll}2.35 & 0.92\end{array}$ & 15 & 0.75 & 0.30 \\
\hline Total $5+6$ & 0.6 & 0.5 & 0.9 & 0.6 & 2.3 & 2.8 & 3.1 & 2.3 & 1.3 & 3.1 & 2.5 & 3 & 1.8 & 2.9 & 1.9 & 1.6 & 1.5 & 0.8 & 1.7 & 1.6 & $\begin{array}{l}2.14 \quad 0.71 \\
\end{array}$ & 26 & 0.65 & 0.17 \\
\hline 7,1 & 0 & 1 & 2 & 2 & 2 & 5 & 4 & 3 & 1 & 1 & 2 & 1 & 1 & 2 & 0 & 1 & 1 & 0 & 0 & 26 & $1.63^{\prime} 1.41^{\prime}$ & 5 & $1.25^{\prime}$ & 0.96 \\
\hline 7,2 & 1 & 2 & 0 & 2 & 2 & 1 & 0 & 2 & 4 & 5 & 3 & 2 & 5 & 1 & 0 & 0 & 1 & 2 & 3 & 31 & $1.94^{\prime} 1.69^{\prime}$ & 5 & $1.25^{\prime}$ & 0.96 \\
\hline 7,3 & 0 & 2 & 0 & 1 & 1 & 4 & 1 & 2 & 0 & 3 & 2 & 0 & 1 & 1 & 2 & 2 & 0 & 2 & 2 & 24 & $1.50^{\prime} 1.10^{\prime}$ & 3 & $0.75^{\prime \prime}$ & 0.96 \\
\hline 7,4 & 2 & 1 & 1 & 0 & 5 & 4 & 1 & 2 & 3 & 1 & 4 & 2 & 0 & 2 & 0 & 3 & 2 & 1 & 2 & 32 & $2.00^{\prime \prime} 1.51^{\prime \prime}$ & 4 & $1.00^{\prime}$ & 0.82 \\
\hline 7,5 & 0 & 2 & 1 & 1 & 3 & 4 & 1 & 3 & 3 & 0 & 2 & 3 & 2 & 4 & 2 & 2 & 2 & 1 & 0 & 32 & $2.00^{\prime} 1.32^{\prime \prime}$ & 4 & $1.00^{\prime}$ & 0.82 \\
\hline Average 7 & 0.6 & 1.6 & 0.8 & 1.2 & 2.6 & 3.6 & 1.4 & 2.4 & 2.2 & 2 & 2.6 & 1.6 & 1.8 & 2 & 0.8 & 1.6 & 1.2 & 1.2 & 1.4 & $0.6^{7}$ & $\begin{array}{lll}1.81 & 0.76^{\prime}\end{array}$ & $21^{\prime}$ & 1.05 & 0.44 \\
\hline 8,1 & 2 & 3 & 2 & 1 & 2 & 5 & 4 & 5 & 1 & 3 & 4 & 4 & 3 & 1 & 2 & 4 & 1 & 0 & 0 & 43 & $2.69^{\prime \prime} 1.70^{\prime \prime}$ & 8 & $2.00^{\prime}$ & 0.82 \\
\hline 8,2 & 0 & 1 & 0 & 0 & 1 & 1 & 1 & 1 & 1 & 2 & 3 & 0 & 0 & 1 & 1 & 0 & 0 & 1 & 0 & 14 & $0.88^{\prime} 0.81^{\prime \prime}$ & 1 & $0.25^{\prime}$ & 0.50 \\
\hline 8,3 & 0 & 0 & 1 & 0 & 1 & 0 & 3 & 4 & 3 & 2 & 3 & 0 & 1 & 4 & 2 & 0 & 1 & 1 & 1 & 28 & $1.75^{\prime \prime} 1.34^{\prime \prime}$ & 1 & $0.25^{\prime}$ & 0.50 \\
\hline 8,4 & 0 & 0 & 1 & 0 & 3 & 3 & 6 & 4 & 4 & 4 & 4 & 3 & 0 & 2 & 1 & 4 & 3 & 4 & 1 & 46 & $2.88^{\prime} 1.67^{\prime \prime}$ & 1 & $0.25^{\prime}$ & 0.50 \\
\hline 8,5 & 0 & 0 & 0 & 1 & 4 & 2 & 3 & 3 & 5 & 4 & 1 & 2 & 3 & 0 & 2 & 0 & 1 & 1 & 1 & 32 & $2.00^{\prime} 1.55^{\prime}$ & 1 & $0.25^{\prime}$ & 0.50 \\
\hline Average 8 & 0.4 & 0.8 & 0.8 & 0.4 & 2.2 & 2.2 & 3.4 & 3.4 & 2.8 & 3 & 3 & 1.8 & 1.4 & 1.6 & 1.6 & 1.6 & 1.2 & 1.4 & 0.6 & 1.4 & $2.04 \quad 0.85$ & 12 & 0.60 & 0.23 \\
\hline Total $7+8$ & 0.5 & 1.2 & 0.8 & 0.8 & 2.4 & 2.9 & 2.4 & 2.9 & 2.5 & 2.5 & 2.8 & 1.7 & 1.6 & 1.8 & 1.2 & 1.6 & 1.2 & 1.3 & 1 & 308 & $1.93 \quad 0.69$ & 33 & 0.83 & 0.29 \\
\hline 9,1 & 1 & 1 & 0 & 0 & 19 & 25 & 2 & 5 & 20 & 8 & 15 & 47 & 3 & 4 & 1 & 4 & 4 & 2 & 3 & $166^{\prime}$ & $10.38^{\prime \prime} 12.32^{\prime \prime}$ & $2^{\prime \prime}$ & $0.50^{\prime \prime}$ & 0.58 \\
\hline 9,2 & 0 & 0 & 1 & 1 & 25 & 52 & 3 & 11 & 27 & 27 & 29 & 17 & 8 & 11 & 5 & 5 & 1 & 0 & 5 & $226^{\prime}$ & $14.13^{\prime} 14.41^{\prime}$ & $2^{\prime}$ & $0.50^{\prime}$ & 0.58 \\
\hline Average 9 & 0.5 & 0.5 & 0.5 & 0.5 & 22 & 38.5 & 2.5 & 8 & 23.5 & 17.5 & 22 & 32 & 5.5 & 7.5 & 3 & 4.5 & 2.5 & 1 & 4 & 196 & 12.2511 .96 & 2 & 0.50 & 0.00 \\
\hline 10,1 & 0 & 1 & 0 & 1 & 58 & 50 & 10 & 20 & 34 & 61 & 61 & 27 & 112 & 9 & 7 & 11 & 3 & 1 & 10 & $478^{\prime}$ & $29.88^{\prime} 30.91^{\prime}$ & $2^{\prime}$ & $0.50^{\prime}$ & 0.58 \\
\hline 10,2 & 1 & 1 & 0 & 2 & 133 & 135 & 33 & 40 & 115 & 70 & 88 & 70 & 19 & 28 & 11 & 20 & 6 & 4 & 8 & $787^{\prime}$ & $49.19^{\prime} 46.54^{\prime \prime}$ & $4^{\prime}$ & $1.00^{\prime}$ & 0.82 \\
\hline Average 10 & 0.5 & 1 & 0 & 1.5 & 95.5 & 92.5 & 21.5 & 30 & 74.5 & 65.5 & 74.5 & 48.5 & 65.5 & 18.5 & 9 & 15.5 & 4.5 & 2.5 & 9 & 632.5 & 39.5333 .54 & 3 & 0.75 & 0.65 \\
\hline Average $9 \& 10$ & 0.5 & 0.75 & 0.25 & 1 & 58.75 & 65.5 & 12 & 19 & 49 & 41.5 & 48.25 & 40.25 & 35.5 & 13 & 6 & 10 & 3.5 & 1.75 & 6.5 & $3.8 \quad 414.25$ & 25.8921 .95 & 2.5 & 0.63 & 0.32 \\
\hline
\end{tabular}




\begin{tabular}{|c|c|c|c|c|c|c|c|c|c|c|c|c|c|c|c|c|c|c|c|c|c|c|c|c|c|}
\hline 11,1 & 0 & 1 & 0 & 2 & 2 & 2 & 1 & 1 & 4 & 4 & 5 & 3 & 5 & 3 & 4 & 4 & 3 & 1 & 1 & 1 & $44^{\prime}$ & $2.75^{\prime} 1.48^{\prime}$ & $3^{7}$ & $0.75^{\prime}$ & 0.96 \\
\hline 11,2 & 0 & 2 & 0 & 1 & 3 & 2 & 0 & 0 & 8 & 4 & 6 & 9 & 0 & 1 & 2 & 3 & 2 & 5 & 1 & $2^{\prime}$ & $48^{\prime}$ & $3.00^{\prime} 2.76^{\prime \prime}$ & $3^{\prime}$ & $0.75^{\prime \prime}$ & 0.96 \\
\hline 11,3 & 0 & 1 & 0 & 2 & 7 & 5 & 8 & 6 & 7 & 8 & 6 & 10 & 5 & 9 & 3 & 3 & 4 & 1 & 1 & $0^{\prime}$ & $83^{\prime}$ & $5.19^{\prime \prime} 2.99^{\prime \prime}$ & $3^{\prime}$ & $0.75^{\prime}$ & 0.96 \\
\hline 11,4 & 1 & 2 & 0 & 2 & 0 & 4 & 6 & 2 & 8 & 4 & 10 & 6 & 1 & 5 & 4 & 2 & 2 & 2 & 4 & $3^{\prime}$ & $63^{\prime \prime}$ & $3.94^{\prime} 2.62^{\prime}$ & $5^{\prime}$ & $1.25^{\prime}$ & 0.96 \\
\hline 11,5 & 1 & 0 & 1 & 1 & 4 & 4 & 3 & 4 & 5 & 4 & 0 & 3 & 2 & 5 & 5 & 1 & 1 & 2 & 2 & $1^{\prime}$ & $46^{\prime}$ & $2.88^{\prime} 1.63^{\prime}$ & $3^{r}$ & $0.75^{\prime}$ & 0.50 \\
\hline Average 11 & 0.4 & 1.2 & 0.2 & 1.6 & 3.2 & 3.4 & 3.6 & 2.6 & 6.4 & 4.8 & 5.4 & 6.2 & $2 \quad 2.6$ & $\begin{array}{ll}5 & 4.6\end{array}$ & 3.6 & 2.6 & 2.4 & 2.2 & $2 \quad 1.8$ & 1.4 & 56.8 & $\begin{array}{ll}3.55 & 1.53\end{array}$ & 3.4 & 0.85 & 0.66 \\
\hline 12,1 & 0 & 2 & 0 & 0 & 2 & 4 & 2 & 1 & 3 & 4 & 5 & 4 & 2 & 5 & 3 & 2 & 1 & 1 & 12 & $1^{\prime}$ & $42^{\prime}$ & $2.63^{\prime \prime} 1.41^{\prime \prime}$ & $2^{\prime}$ & $0.50^{\prime \prime}$ & 1.00 \\
\hline 12,2 & 2 & 2 & 1 & 1 & 7 & 10 & 5 & 5 & 4 & 3 & 3 & 5 & 2 & 3 & 3 & 2 & 1 & 0 & 3 & 1 & $57^{\prime \prime}$ & $3.56^{\prime} 2.48^{\prime \prime}$ & $6^{\prime}$ & $1.50^{\prime}$ & 0.58 \\
\hline 12,3 & 1 & 3 & 1 & 1 & 14 & 7 & 13 & 14 & 13 & 14 & 15 & 9 & 14 & 5 & 9 & 8 & 5 & 8 & 5 & 5 & $158^{\prime}$ & $9.88^{\prime} 3.88^{\prime \prime}$ & $6^{7}$ & $1.50^{\prime}$ & 1.00 \\
\hline 12,4 & 1 & 1 & 1 & 2 & 7 & 4 & 9 & 8 & 7 & 13 & 5 & 6 & 6 & 4 & 5 & 4 & 3 & 2 & 0 & $0^{\prime}$ & $83^{\prime \prime}$ & $5.19^{\prime} 3.31^{\prime \prime}$ & $5^{\prime}$ & $1.25^{\prime}$ & 0.50 \\
\hline 12,5 & 0 & 0 & 0 & 1 & 1 & 2 & 4 & 4 & 5 & 2 & 2 & 3 & 3 & 2 & 0 & 4 & 1 & 1 & 1 & $0^{\prime}$ & $35^{\prime}$ & $2.19^{\prime} 1.52^{\prime}$ & $1^{\prime}$ & $0.25^{\prime}$ & 0.50 \\
\hline Average 12 & 0.8 & 1.6 & 0.6 & 1 & 6.2 & 5.4 & 6.6 & 6.4 & 6.4 & 7.2 & 6 & 5.4 & 5.4 & 3.8 & 4 & 4 & 2.2 & 2.4 & $\begin{array}{ll}4 \quad 2.2 \\
\end{array}$ & 1.4 & 75 & $\begin{array}{ll}4.69 & 1.85\end{array}$ & 4 & 1.00 & 0.43 \\
\hline Average $11+12$ & 0.6 & 1.4 & 0.4 & 1.3 & 4.7 & 4.4 & 5.1 & 4.5 & 6.4 & 6 & 5.7 & 5.8 & 4 & $4 \quad 4.2$ & 3.8 & 3.3 & $\begin{array}{ll}3 \quad 2.3 \\
\end{array}$ & 2.3 & 2 & 1.4 & 65.9 & $4.12 \quad 1.53$ & 3.7 & 0.93 & 0.50 \\
\hline 13,1 & 0 & 0 & 0 & 1 & 5 & 9 & 4 & 0 & 3 & 6 & 1 & 4 & 2 & 3 & 4 & 4 & 4 & 0 & 2 & $1^{\prime}$ & $40^{\prime}$ & $2.50^{\prime \prime} 1.37^{\prime \prime}$ & $3^{\prime}$ & $0.75^{\prime}$ & 0.50 \\
\hline 13,2 & 0 & 2 & 1 & 1 & 3 & 3 & 0 & 7 & 6 & 3 & 5 & 1 & 0 & 4 & 1 & 2 & 1 & 1 & 1 & $0^{\prime \prime}$ & $70^{\prime}$ & $4.38^{\prime \prime} 2.66^{\prime \prime}$ & $1^{\prime}$ & $0.25^{\prime}$ & 0.50 \\
\hline 13,3 & 2 & 0 & 1 & 2 & 4 & 6 & 2 & 3 & 4 & 4 & 0 & 2 & 4 & 1 & 3 & 3 & 3 & 1 & 0 & $0^{\prime \prime}$ & $61^{\prime}$ & $3.81^{\prime} 2.97^{\prime \prime}$ & $2^{\prime}$ & $0.50^{\prime \prime}$ & 1.00 \\
\hline 13,4 & 0 & 0 & 0 & 0 & 4 & 2 & 4 & 6 & 4 & 4 & 2 & 3 & 1 & 2 & 4 & 4 & 4 & 0 & 1 & $0^{\circ}$ & $69^{\prime}$ & $4.31^{\prime \prime} 2.60^{\prime}$ & $1^{\prime}$ & $0.25^{\prime}$ & 0.50 \\
\hline 13,5 & 1 & 1 & 1 & 0 & 4 & 2 & 5 & 4 & 4 & 4 & 5 & 4 & 2 & 2 & 2 & 4 & 1 & 0 & 3 & $1^{\prime \prime}$ & $57^{\prime}$ & $3.56^{\prime} 1.97^{\prime}$ & $6^{7}$ & $1.50^{\prime}$ & 0.58 \\
\hline Average 13 & 0.6 & 0.6 & 0.6 & 0.8 & 4 & 4.4 & 3 & 4 & 4.2 & 4.2 & 2.6 & 2.8 & $3 \quad 1.8$ & 2.4 & 2.8 & 3.4 & 2.6 & 0.4 & $\begin{array}{ll}4 & 1.4\end{array}$ & 0.4 & 44.4 & $\begin{array}{ll}2.78 & 1.28\end{array}$ & 2.6 & 0.65 & 0.10 \\
\hline 14,1 & 1 & 1 & 0 & 1 & 0 & 3 & 2 & 4 & 3 & 2 & 5 & 2 & 4 & 2 & 2 & 4 & 0 & 3 & 2 & $2^{2}$ & $40^{\prime}$ & $2.50^{\prime \prime} 1.37^{\prime \prime}$ & $3^{\prime}$ & $0.75^{\prime \prime}$ & 0.50 \\
\hline 14,2 & 0 & 1 & 0 & 0 & 4 & 3 & 3 & 6 & 9 & 9 & 9 & 6 & 4 & 3 & 4 & 3 & 2 & 2 & 2 & 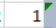 & $70^{\prime}$ & $4.38^{\prime} 2.66^{\prime}$ & $1^{\prime}$ & $0.25^{\prime}$ & 0.50 \\
\hline 14,3 & 0 & 0 & 2 & 0 & 2 & 4 & 3 & 2 & 9 & 9 & 7 & 8 & 1 & 6 & 2 & 3 & 1 & 1 & 1 & & $61^{\prime \prime}$ & $3.81^{\prime \prime} 2.97^{\prime}$ & $2^{\prime}$ & $0.50^{\prime}$ & 1.00 \\
\hline 14,4 & 0 & 0 & 0 & 1 & 7 & 8 & 5 & 4 & 8 & 7 & 3 & 6 & 1 & 6 & 4 & 5 & 2 & 2 & 0 & $1^{\prime}$ & $69^{\prime \prime}$ & $4.31^{\prime \prime} 2.60^{\prime \prime}$ & $1^{\prime}$ & $0.25^{\prime}$ & 0.50 \\
\hline 14,5 & 2 & 2 & 1 & 1 & 8 & 2 & 3 & 7 & 3 & 3 & 5 & 4 & 6 & 2 & 3 & 3 & 2 & 2 & 1 & 3 & $57^{\prime}$ & $3.56^{\prime} 1.97^{\prime \prime}$ & $6^{\prime}$ & $1.50^{\prime \prime}$ & 0.58 \\
\hline Average 14 & 0.6 & 0.8 & 0.6 & 0.6 & 4.2 & 4 & 3.2 & 4.6 & 6.4 & 6 & 5.8 & 5.2 & $2 \quad 3.2$ & 3.8 & 3 & 3.6 & 5 1.4 & 2 & $2 \quad 1.2$ & 1.8 & 59.4 & $\begin{array}{ll}3.71 \quad 1.62\end{array}$ & 2.6 & 0.65 & 0.10 \\
\hline Average $13+14$ & 0.6 & 0.7 & 0.6 & 0.7 & 4.1 & 4.2 & 3.1 & 4.3 & 5.3 & 5.1 & 4.2 & 4 & $4 \quad 2.5$ & $5 \quad 3.1$ & 2.9 & 3.5 & 2 & 1.2 & 21.3 & 1.1 & 51.9 & $3.24 \quad 1.34$ & 2.6 & 0.65 & 0.06 \\
\hline Average per plat & 0.6 & 0.9 & 0.733 & 0.867 & 3.483 & 3.08333 & 3.083 & 3.1667 & 3.367 & 3.95 & 3.4 & 3.433 & 2.417 & 7.533 & 32.283 & 2.283 & 1.55 & 1.55 & $5 \quad 1.6$ & 1.3 & & & & & \\
\hline STD per plate & 0.21 & 0.47 & 0.33 & 0.44 & 1.22 & 1.15 & 1.36 & 1.39 & 1.99 & 1.67 & 1.50 & 1.43 & $\begin{array}{ll}3 & 1.20 \\
\end{array}$ & 1.07 & 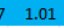 & 0.95 & 0.60 & 0.81 & 10.59 & 0.51 & & & & & \\
\hline
\end{tabular}




\section{Appendix D: Extra Statistic Tests}

\begin{tabular}{|c|c|c|c|c|c|c|c|c|c|c|c|c|c|c|c|c|}
\hline T-Test & Versoflo & vs. & $\mathrm{N}-95$ & & & & & & & & & & & & & \\
\hline & 1 & 2 & 3 & 4 & 5 & 6 & 7 & 8 & 9 & 10 & 11 & 12 & 13 & 14 & 15 & 16 \\
\hline$p$-Value & 0.0427 & 0.264 & 0.476 & 0.888 & 0.868 & 0.04382 & 0.616 & 0.0193 & 0.556 & 0.503 & 0.169 & 0.505 & 0.841 & 0.055 & 0.037 & 0.865 \\
\hline Rank & 3 & 7 & 8 & 16 & 15 & 4 & 12 & 1 & 11 & 9 & 6 & 10 & 13 & 5 & 2 & 14 \\
\hline Alpha & 0.0036 & 0.005 & 0.006 & 0.05 & 0.025 & 0.00385 & 0.01 & 0.0031 & 0.008 & 0.006 & 0.005 & 0.007 & 0.013 & 0.004 & 0.003 & 0.017 \\
\hline Significant & NO & NO & NO & NO & NO & NO & NO & NO & NO & NO & NO & NO & NO & NO & NO & NO \\
\hline \multirow[t]{2}{*}{ T-Test } & Versoflo & vs. & ir-Mat & & & & & & & & & & & & & \\
\hline & 1 & 2 & 3 & 4 & 5 & 6 & 7 & 8 & 9 & 10 & 11 & 12 & 13 & 14 & 15 & 16 \\
\hline$p$-Value & 0.464 & 0.653 & 0.159 & 0.545 & 0.933 & 0.02556 & 0.184 & 0.6595 & 0.953 & 0.582 & 0.545 & 0.402 & 0.523 & 0.074 & 0.055 & 0.46 \\
\hline Rank & 8 & 13 & 4 & 11 & 15 & 1 & 5 & 14 & 16 & 12 & 10 & 6 & 9 & 3 & 2 & 7 \\
\hline Alpha & 0.0056 & 0.013 & 0.004 & 0.008 & 0.025 & 0.00313 & 0.004 & 0.0167 & 0.05 & 0.01 & 0.007 & 0.005 & 0.006 & 0.004 & 0.003 & 0.005 \\
\hline Significant & No & No & No & No & NO & NO & NO & No & NO & NO & No & NO & NO & NO & No & NO \\
\hline
\end{tabular}

